\title{
PERSCRUTAMENTO GRÁFICO DOS INDICADORES DE VARIABILIDADE DE VAZÃO NA SUB-BACIA 87
}

\author{
Francisco F. N. Marcuzzo ${ }^{1}$ \& Flora W. Simon ${ }^{2}$
}

Resumo - Na gestão de águas superficiais e subterrâneas, além do seu planejamento a médio e longo prazo, é cabível, para um mais perfeito entendimento do escoamento superficial e de base, lançar mão de estudos da relação da diversidade dos indicadores regionais da vazão dos cursos d'água da bacia hidrográfica. O objetivo foi investigar graficamente as relações dos indicadores de variabilidade regional de vazão de estações fluviométricas com mais de cinco anos de dados, na sub-bacia da Lagoa dos Patos, frente à sua área de drenagem e precipitação média anual. Foram calculados e plotados em gráficos de dispersão o coeficiente de variação da vazão média anual de longo período, coeficiente de variação de $95 \%$ da vazão de permanência, a relação da vazão de permanência a 50 e $95 \%$ do tempo com a vazão média de longo termo, coeficiente de escoamento superficial, vazões médias específicas de longo período e de $95 \%$ de permanência. Concluiu-se que relação da vazão de permanência 95\%, os maiores valores estão em estações locadas em quatro subbacias distintas, que estão nas formações hidrogeológicas denominadas Sistema Aquífero Embasamento Cristalino I e III, e Sistema Aquífero Quaternário Costeiro I e II.

\begin{abstract}
Management of surface and groundwater in addition to its planning in the medium and long term, it is appropriate, for a more perfect understanding of runoff and base, make use of diversity of relationship studies of regional flow indicators of the water course catchment area. The objective was to graphically investigate the relationship of regional variability of indicators of flow gauged stations with more than five years of data, the sub-basin of the Lagoa dos Patos (lagoon), opposite its drainage area and mean annual precipitation. Were calculated and plotted in scatter plots the coefficient of variation of the average annual flow of long period, coefficient of variation of $95 \%$ of the length of flow, the ratio of the length of flow at 50 and $95 \%$ of the time with the average flow over term, runoff coefficient, average flow rates of specific long period and $95 \%$ of stay. It was concluded that the relative permanence of flow 95\%, the highest values are in leased stations in four distinct sub-basins that are in hydrogeological formations called Aquifer System Crystalline Basement I and III, and Quaternary Coastal Aquifer System I and II.
\end{abstract}

Palavras-Chave - Regionalização de Vazões, Lagoa dos Patos, Guaíba.

\footnotetext{
${ }^{1 *}$ Pesquisador(a) em Geociências, CPRM/SGB (Companhia de Pesquisa de Recursos Minerais / Serviço Geológico do Brasil) - Rua Banco da Província, $n^{\circ} 105$ - Santa Tereza - CEP 90840-030, Porto Alegre/RS. Tel.: (51) 3406-7324. francisco.marcuzzo@ @prm.gov.br.

${ }^{2}$ Engenheira Ambiental, ex-estagiária do projeto de Regionalização de Vazões da Sub-Bacia 87, CPRM / SGB. florawsimon@ gmail.com. 


\section{INTRODUÇÃO}

O foco do estudo de indicadores da variabilidade regional é a identificação de possíveis agrupamentos de estações com comportamento hidrológico semelhante que possibilitem a regionalização desta variável. Não somente, mas principalmente os indicadores de vazões mínimas estão intrinsicamente associados ao comportamento da vazão de base, ou seja, é diretamente dependente da vazão mantida pela água subterrânea existente nos aquíferos da região.

Em um estudo do regime hídrico pluvial e fluvial da sub-bacia da Lagoa dos Patos no Rio Grande do Sul, Simon et al. (2013) concluíram que 16 das 25 estações fluviométricas estudadas apresentaram um período de maior disponibilidade hídrica devido ao aumento da descarga líquida entre abril e outubro. Os autores verificaram que nove outras estações possuem este período de maior disponibilidade hídrica entre abril e dezembro, com variações entre as estações. Os autores conseguiram diferenciar, para a quase totalidade da sub-bacia da Lagoa dos Patos, um período com maior disponibilidade hídrica por descarga líquida dos rios, de abril a outubro, de um período com menor disponibilidade hídrica, de novembro a março.

Em um estudo sobre indicadores de vazão na bacia da Lagoa dos Patos, Marcuzzo et al. (2014) concluíram que para o indicador Coeficiente de Escoamento, observou-se que os menores valores ocorrem em estações ao longo do rio Camaquã, que estão sobre as formações hidrogeológicas Sistema Aquífero Embasamento Cristalino II (ec2) e Sistema Aquífero Quaternário Indiferenciado (qi), enquanto que os maiores valores ocorrem para todas as estações da sub-bacia do Litoral Norte, que estão sobre as formações hidrogeológicas Sistema Aquífero Quaternário Costeiro I (qc1) e no Sistema Aquífero Quaternário Costeiro II (qc2), além de estações em outras sub-bacias que estão sobre as formações Sistemas Aquíferos Embasamento Cristalino I, II e II $($ ec1,ec2 e ec3).

Outros estudos contemplando relações de vazões com pluviosidade de diferentes áreas foram conduzidos por Manzione et al. (2009), Manzione et al. (2010), Manzione et al. (2012) e Machado e Marcuzzo (2015), conduzida pela função de impulso e resposta, sendo aplicável também para vazão, tornando-se viável o estudo direto de diferentes tipos de fenômenos, que alteram o nível freático e, por conseguinte, a recarga de aquíferos. Virães (2010) e Virães (2013), em um estudo de regionalização e vazões na sub-bacia 50, cita que se calculam os indicadores hidrológicos regionais e características estatísticas para análise de sua variabilidade espacial, visando auxiliar a definição das regiões hidrológicas e estatisticamente homogêneas. As análises mais qualitativas de mapas temáticos auxiliaram a definição dos limites dessas regiões.

O presente trabalho tem por objetivo pesquisar as relações gráficas dos indicadores de variabilidade regional de vazão de estações fluviométricas, com mais de cinco anos de dados, na sub-bacia 87, frente à sua variação na área de drenagem e precipitação média anual. 


\section{MATERIAL E MÉTODOS}

\section{Área de estudo, altimetria, clima e pluviosidade da sub-bacia e dados utilizados no estudo}

A sub-bacia 87 (Figura 1) está situada na região leste do estado do Rio Grande do Sul. Possui área de drenagem de $58.415 \mathrm{~km}^{2}$ e, como corpo d'água principal, a Lagoa dos Patos.

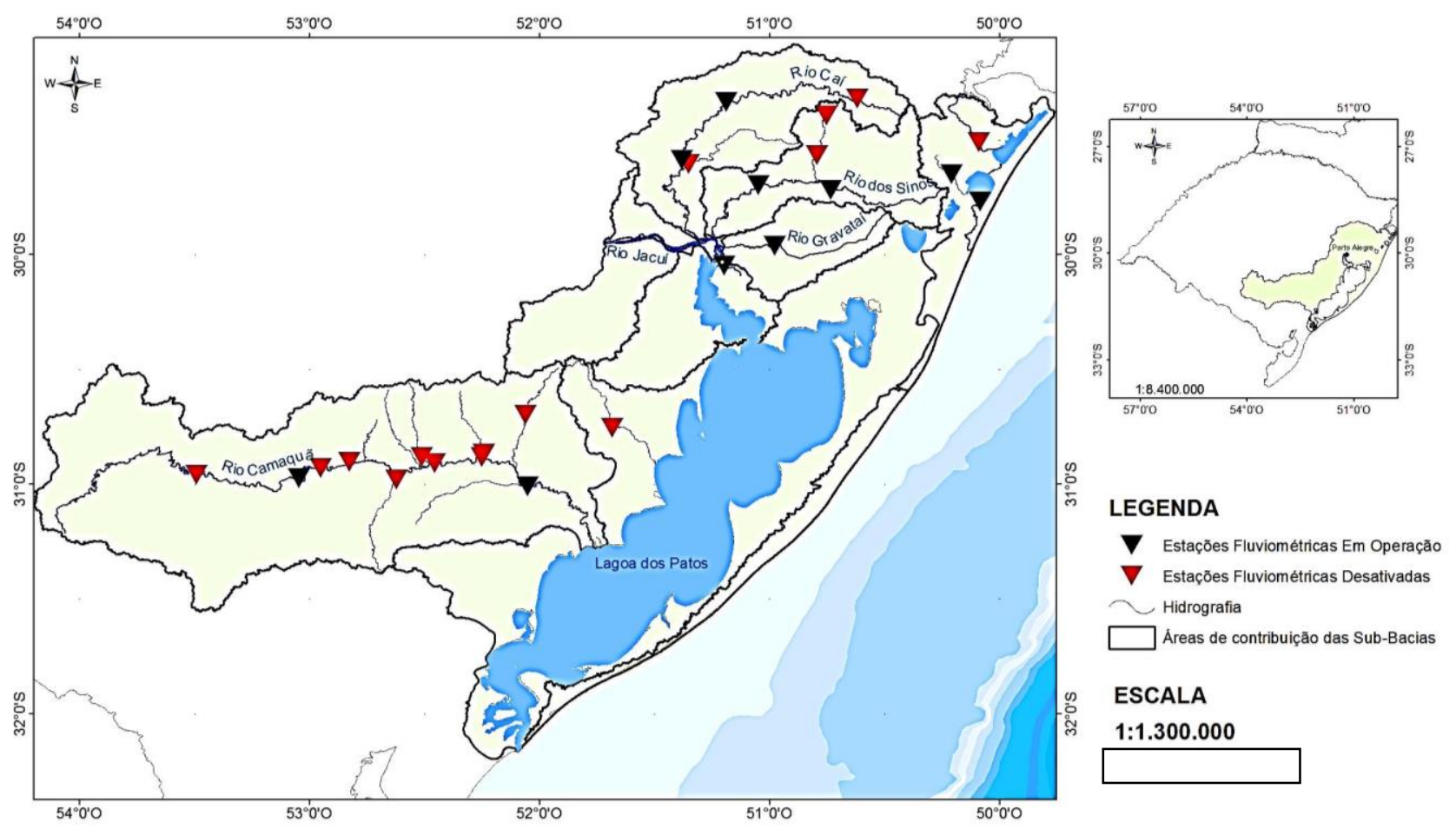

Figura 1 - Localização das estações fluviométricas ativas e desativadas na sub-bacia 87

Na caracterização altimétrica da sub-bacia 87, de acordo com Tschiedel et al. (2012) as altitudes mais elevadas de toda a sub-bacia ocorrem ao norte, atingindo 1000 metros em determinadas regiões, pois compreende parte da serra do Rio Grande do Sul. Para a caracterização pluviométrica geral da sub-bacia 87, apresentada a seguir, utilizou-se dos resultados apresentados no Atlas Pluviométrico do Brasil (PINTO et al., 2011), com dados de precipitação compreendidos entre 1977 a 2006. Estes dados estão também disponíveis em Brasil (2013) e também foram utilizados no estudo elaborado por Simon et al. (2013), Melati (2015) e por Kich et al. (2015). Foram utilizados os dados de 25 estações FD, das quais 15 estão desativadas (BRASIL, 2013).

Foram calculados e plotados em gráficos de dispersão os seguintes indicadores de variabilidade regional: $\mathrm{CVQ}_{\mathrm{mlt}}$ (coeficiente de variação da vazão média anual de longo período), CVQ 95 Anual (coeficiente de variação de 95\% da vazão de permanência), rcp50 (relação da vazão de permanência a 50\% do tempo com a vazão média de longo termo), rcp95 (relação da vazão de permanência a $95 \%$ do tempo com a vazão média de longo termo), $\mathrm{C}_{\text {escoamento (coeficiente de }}$

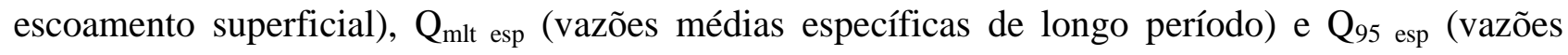
médias específicas com $95 \%$ de permanência). O detalhamento das equações utilizadas pode ser obtido em Tucci (2002), Naghettini e Pinto (2007), Virães (2013) e Marcuzzo e Pickbrenner (2016). 


\section{RESULTADOS E DISCUSSÃO}

Observa-se na Figura 2 que o Coeficiente de Variação da $\mathrm{Q}_{\mathrm{mlt}}$, considerando a área de drenagem, apresenta valores entre 0,20 e 0,70 para os rios principais e entre 0,10 e 0,50 para os rios afluentes. O valor mais baixo de $\mathrm{CVQ}_{\mathrm{mlt}}$ em estações fluviométricas nos rios principais, de 0,28, ocorre para a estação Passo São José (código 87840000, área de drenagem de 12732km²), localizada no rio Camaquã. Nos rios afluentes os valores mais baixos, menores que 0,28, ocorrem para as estações Passo Pantanoso (código 87780000, área de drenagem 464km²) em Arroio Pantanoso, Passo Maria Santa (código 87810000, área de drenagem $391 \mathrm{~km}^{2}$ ) em Arroio Santa Maria e Passo dos Ladrões (código 87850000, área de drenagem 788km²) em Arroio dos Ladrões, na sub-bacia do rio Camaquã, além das estações Costa do Rio Cadeia (código 87250000, área de drenagem $865 \mathrm{~km}^{2}$ ) em rio Cadeia, Igrejinha (código 87372000 , área de drenagem $469 \mathrm{~km}^{2}$ ) em rio Santa Maria e Camaquã I (código 87530000, área de drenagem $591 \mathrm{~km}^{2}$ ) em Arroio Velhaço. Os valores mais elevados de $\mathrm{CVQ}_{\mathrm{mlt}}$ em estações fluviométricas nos rios principais ocorrem para três estações localizadas no rio Camaquã, com valor médio de 0,55, para as estações Passo do Cação (código 87590000, área de drenagem 4073km²), Passo das Carretas (código 87670000, área de drenagem $7541 \mathrm{~km}^{2}$ ) no curso alto do rio e Passo do Mendonça (código 87590000, área de drenagem $15557 \mathrm{~km}^{2}$ ) no curso baixo do rio. Nos rios afluentes, o valor mais elevado deste indicador, de 0,46, ocorre para a estação Passo do Louro (código 87366000, área de drenagem $101 \mathrm{~km}^{2}$ ) em Rio Santa Maria, na sub-bacia do rio dos Sinos. Os valores que apresentam menor dispersão indicam menor heterogeneidade (maior homogeneidade) dos dados da $\mathrm{Q}_{\text {mlt. }}$.

Verifica-se na Figura 2 que o Coeficiente de Variação da $Q_{\text {mlt }}$, considerando a precipitação pluviométrica média a montante da estação, apresenta-se distribuído em valores aproximadamente homogêneos de precipitação em cada sub-bacia. Isto pode ser visualizado principalmente na subbacia do rio Camaquã, que apresenta precipitação em torno de $1.500 \mathrm{~mm}$ para todas as estações localizadas ao longo do rio. No rio Caí as estações Nova Palmira (código 87160000) e Barca do Caí (código 87170000) apresentam precipitação próxima a 1.700mm, e valores de CVQmlt próximos a 0,37. Para os rios afluentes, visualiza-se valores de $\mathrm{CVQ}_{\mathrm{mlt}}$ próximos (cerca de 0,25), com precipitação em torno de $1500 \mathrm{~mm}$, para as estações Passo dos Ladrões (código 87850000) em Arroio dos Ladrões e Passo Maria Santa (código 87810000) em Arroio Santa Maria, ambas localizadas em afluentes que desaguam na margem esquerda do rio Camaquã. Ainda para os rios afluentes, visualiza-se valores de $\mathrm{CVQ}_{\mathrm{mlt}}$ próximos (cerca de 0,40), com precipitação em torno de 1580mm, para as estações Dom Feliciano (código 87865000) em Arroio Sutil e Itati (código 87317030) em Rio Três Forquilhas, ambas únicas estações de seus respectivos afluentes. 

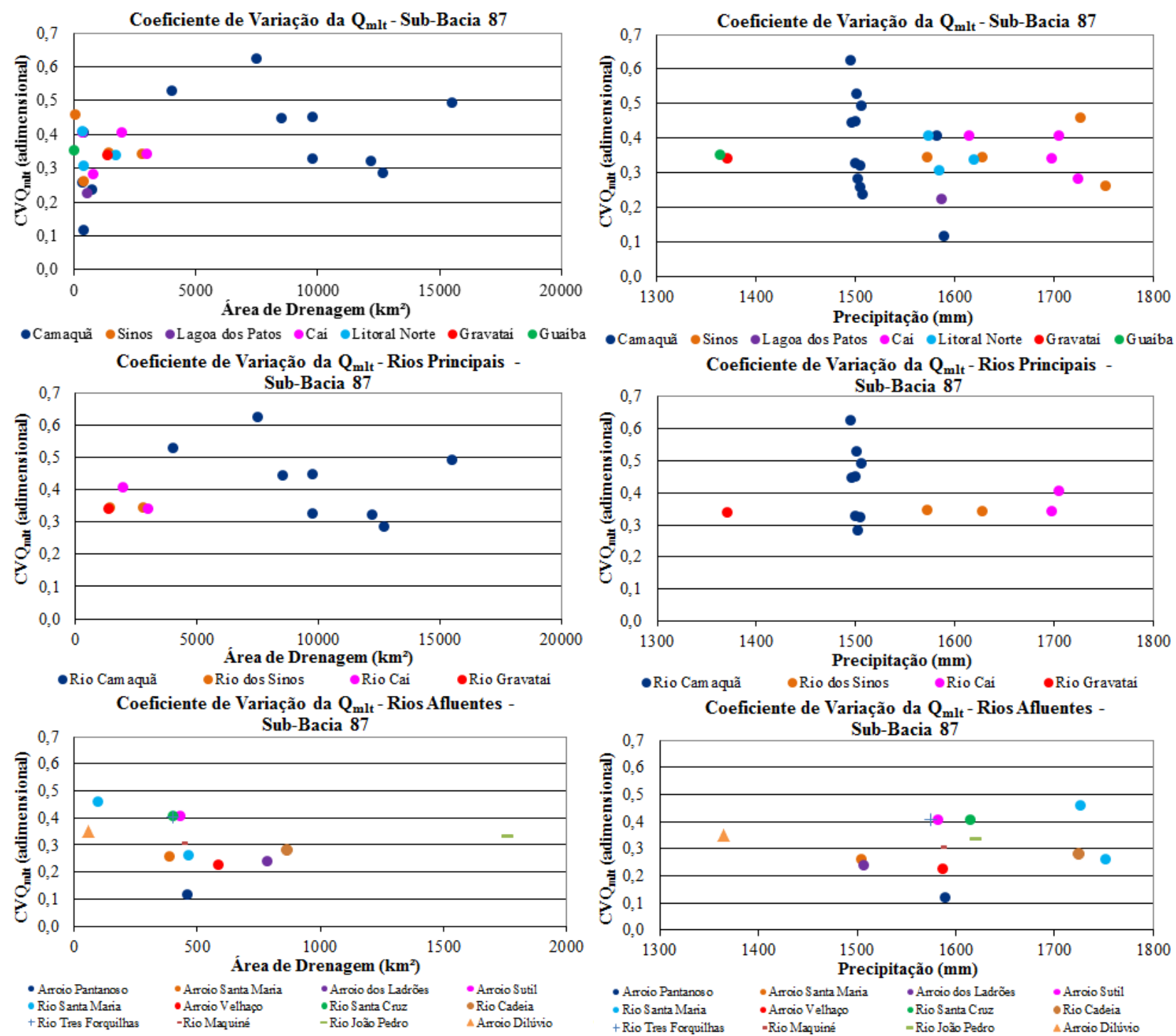

Figura 2 - Dispersão do indicador da variabilidade regional coeficiente de variação da vazão média anual, das estações fluviométricas utilizadas neste estudo, segundo a sua respectiva área de drenagem e precipitação média anual, plotadas por sub-bacia, rios principais e rios afluentes.

Os valores mais baixos de $\mathrm{CVQ}_{95 \mathrm{Anual}}$ em estações fluviométricas nos rios principais ocorrem para as estações Taquara-Montante (código 87374000, área de drenagem 1.466km²) e Campo Bom (código 87380000 , área de drenagem $2858 \mathrm{~km}^{2}$ ), com média de 0,50 no rio dos Sinos , e para a estação Barca do Caí (código 87170000, área de drenagem 3026km²) com 0,43 no rio Caí. Já para os rios afluentes, os valores mais baixos ocorrem para a estação Passo dos Ladrões (código 87850000, área de drenagem $788 \mathrm{~km}^{2}$ ) em Arroio dos Ladrões, com 0,25, e para a estação Passo Maria Santa $\left(87810000\right.$, área de drenagem $391 \mathrm{~km}^{2}$ ) em Arroio Santa Maria, com 0,36. Os valores mais elevados de $\mathrm{CVQ}_{95}$ Anual em estações fluviométricas nos rios principais ocorrem para duas estações localizadas no curso alto do rio Camaquã, que são Passo do Cação (código 87590000, área de drenagem 4073km²), com 1,55, e Passo das Carretas (código 87670000, área de drenagem $7541 \mathrm{~km}^{2}$ ), com 1,14. Nos rios afluentes, o valor mais elevado de CVQ 95 Anual ocorre para a estação Passo Pantanoso (código 87780000, área de drenagem 464km²) em Arroio Pantanoso, na sub-bacia 
do rio Camaquã. Os valores que apresentam menor dispersão indicam menor heterogeneidade (maior homogeneidade) dos dados da $\mathrm{CVQ}_{95 \text { Anual }}$.
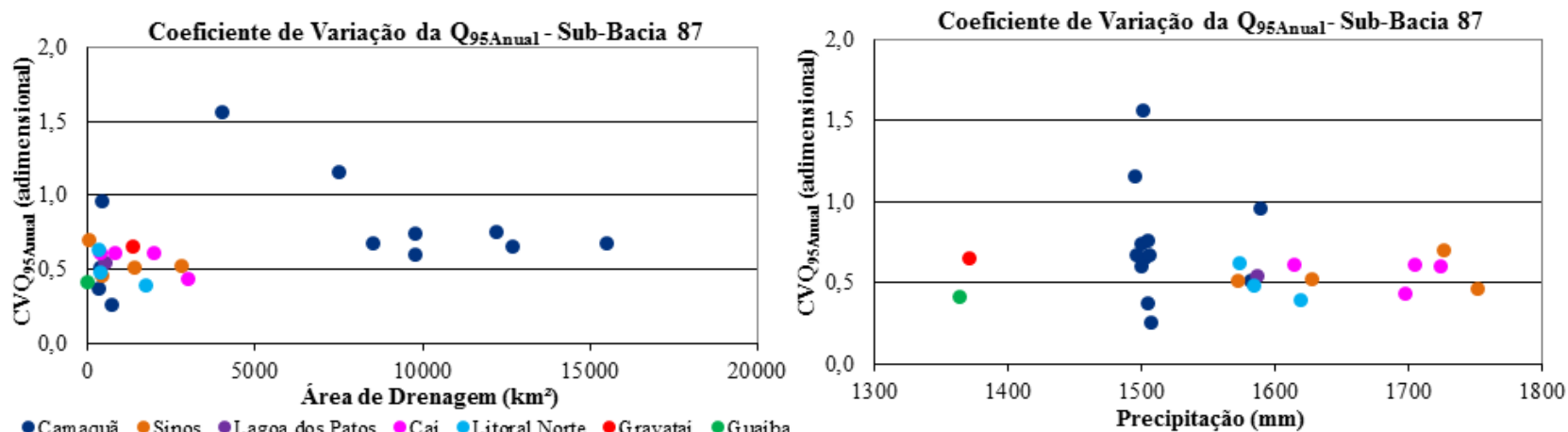

$\bullet$ Camaquã $\bullet$ Sinos $\bullet$ Lagoa dos Patos $\bullet$ Cai $\bullet$ Litoral Norte $\bullet$ Gravatai $\bullet$ Guaiba

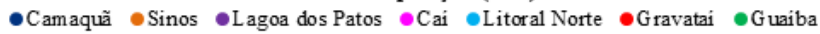
Coeficiente de Variação da $Q_{95 \text { Anual }}$ Rios Principais Sub-Bacia 87
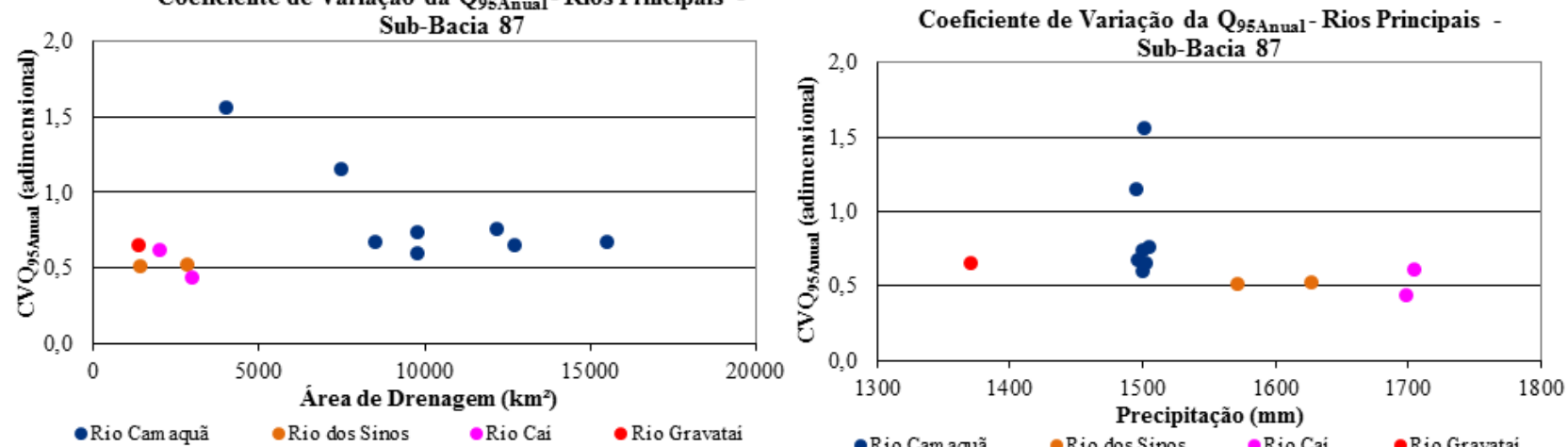

Coeficiente de Variação da $Q_{95 \text { Anual }}$ - Rios Afluentes -
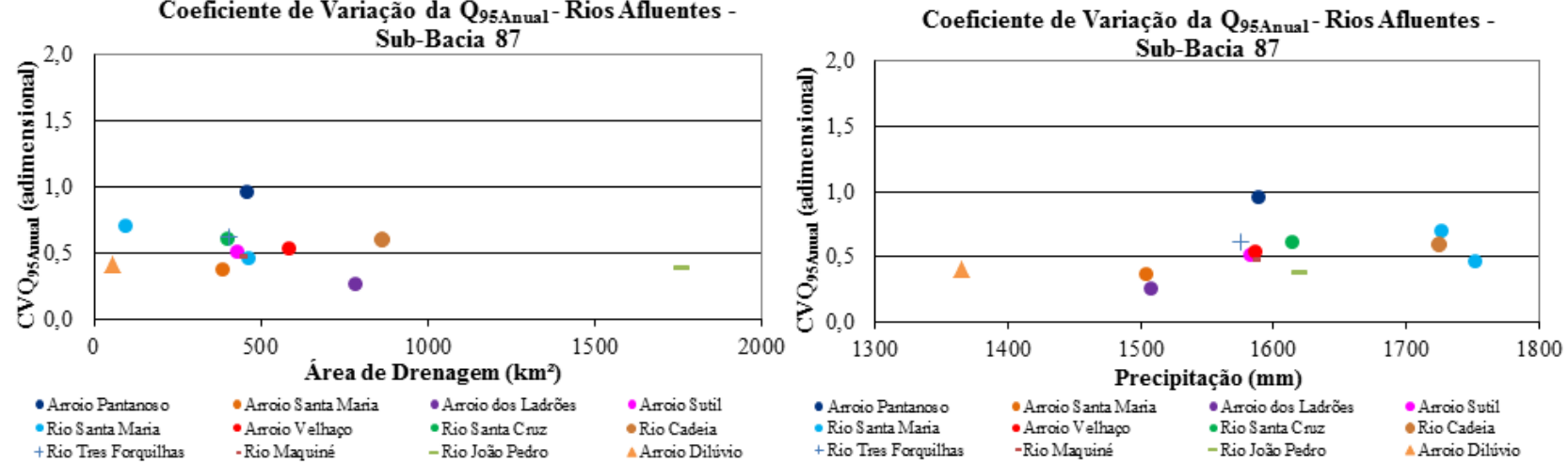

Figura 3 - Dispersão do indicador da variabilidade regional coeficiente de variação de $95 \%$ da vazão de permanência, das estações fluviométricas utilizadas neste estudo, segundo a área de drenagem e a precipitação média anual, plotadas por sub-bacia, rios principais e rios afluentes.

Verifica-se também na Figura 3 que o Coeficiente de Variação da Q95Anual considerando a precipitação pluviométrica média a montante da estação, apresenta-se distribuída em valores aproximadamente homogêneos de precipitação em cada sub-bacia. Isto pode ser visualizado principalmente na sub-bacia do rio Camaquã, que apresenta precipitação em torno de $1500 \mathrm{~mm}$ para todas as estações localizadas ao longo do rio. No rio dos Sinos as estações Taquara Montante (código 87374000) e Campo Bom (código 87380000) apresentam valor aproximado de CVQ95Anual de 0,50 para precipitação média de $1600 \mathrm{~mm}$. Para os rios afluentes, visualiza-se valores da CVQ 95 Anual próximos (cerca de 0,50), com precipitação em torno de $1585 \mathrm{~mm}$, para as estações Dom 
Feliciano (87865000, sub-bacia do rio Camaquã) em Arroio Sutil, Camaquã I (87530000, sub-bacia da Lagoa dos Patos) em Arroio Velhaço e Maquiné (87317030, sub-bacia do Litoral Norte) em Rio Maquiné, todas estações únicas nos seus respectivos rios e sub-bacias.

Observa-se na Figura 4 que a rcp $_{50}$, considerando a área de drenagem, apresenta valores entre 0,30 e 0,70 para os rios principais e entre 0,30 e 0,90 para os rios afluentes. Os valores mais baixos em estações fluviométricas nos rios principais para a $\mathrm{rcp}_{50}$ ocorrem para todas as estações localizadas ao longo do rio Camaquã, e variam em torno de 0,40. Nota-se que os valores da $\mathrm{Q}_{\mathrm{mlt}}$ distancia-se dos valores da $\mathrm{Q}_{50}$, resultando valores maiores que o dobro da mesma. Para as estações localizadas nos rios Caí e Sinos, os valores ficam em torno de 0,45 e 0,60, respectivamente, para áreas de drenagens próximas. Visualiza-se no gráfico dos rios afluentes, que os maiores valores de rcp $_{50}$ ocorrem no Arroio Velhaço, onde está instalada a estação Camaquã I (código 87530000, subbacia da Lagoa dos Patos, área de drenagem $591 \mathrm{~km}^{2}$ ), e no Rio João Pedro, onde está instalada a estação Barra do João Pedro - Montante (código 87317060, sub-bacia do Litoral Norte, área de drenagem $1765 \mathrm{~km}^{2}$ ). O valor elevado deste indicador pode ser explicado devido a proximidade da $\mathrm{Q}_{50}$ com a $\mathrm{Q}_{\mathrm{mlt}}$ para estas duas estações. Verifica-se também na Figura 4 que a rcp ro $_{50}$, considerando a precipitação pluviométrica média a montante da estação, apresenta-se distribuída em valores aproximadamente homogêneos de precipitação em cada sub-bacia. Isto pode ser visualizado principalmente na sub-bacia do rio Camaquã, que apresenta precipitação em torno de $1500 \mathrm{~mm}$ para todas as estações localizadas ao longo do rio. No rio Caí as estações Nova Palmira (código 87160000) e Barca do Caí (código 87170000) apresentam precipitação próxima a 1700mm, e o mesmo valor de 0,45 pra a rcp50. Para os rios afluentes, visualiza-se valores da rcp50 próximos (cerca de 0,48), com precipitação em torno de 1500mm, para as estações Passo dos Ladrões (código 87850000) em Arroio dos Ladrões e Passo Maria Santa (código 87810000) em Arroio Santa Maria, ambas localizadas em afluentes que desaguam na margem esquerda do rio Camaquã.

Observa-se na Figura 5 que a $\mathrm{rcp}_{95}$, considerando a área de drenagem, apresenta aproximadamente valores entre 0,01 e 0,15 para os rios principais e entre 0,005 e 0,40 para os rios afluentes. Os valores mais baixos em estações fluviométricas nos rios principais ocorrem para todas as estações localizadas ao longo do rio Camaquã, e variam em torno de 0,05, indicando maior variação de vazão no rio durante os períodos de estiagem e com baixa capacidade de regularização natural (TUCCI, 2002), além de demonstrar que a $Q_{95}$ é muito menor que a $Q_{\text {mlt. }}$ Para as estações localizadas nos rios Caí, Sinos e Gravataí, os valores ficam em torno de 0,05 e 0,15. Visualiza-se no gráfico dos rios afluentes, que o maior valor encontrado para este indicador, de 0,356, ocorre no Rio João Pedro, onde está instalada a estação Barra do João Pedro - Montante (código 87317060, área de drenagem $1765 \mathrm{~km}^{2}$, sub-bacia do Litoral Norte). O valor elevado da rcp 95 para esta estação indica menor variação de vazão no rio durante os períodos de estiagem e boa capacidade de 
regularização natural (TUCCI, 2002), e o valor da Q95 está mais próximo da Qmlt do que para todas as outras estações. Quanto aos outros rios afluentes, os valores da rcp95 encontram-se entre 0,00 e 0,20 , próximos, portanto, dos valores encontrados para os rios principais.
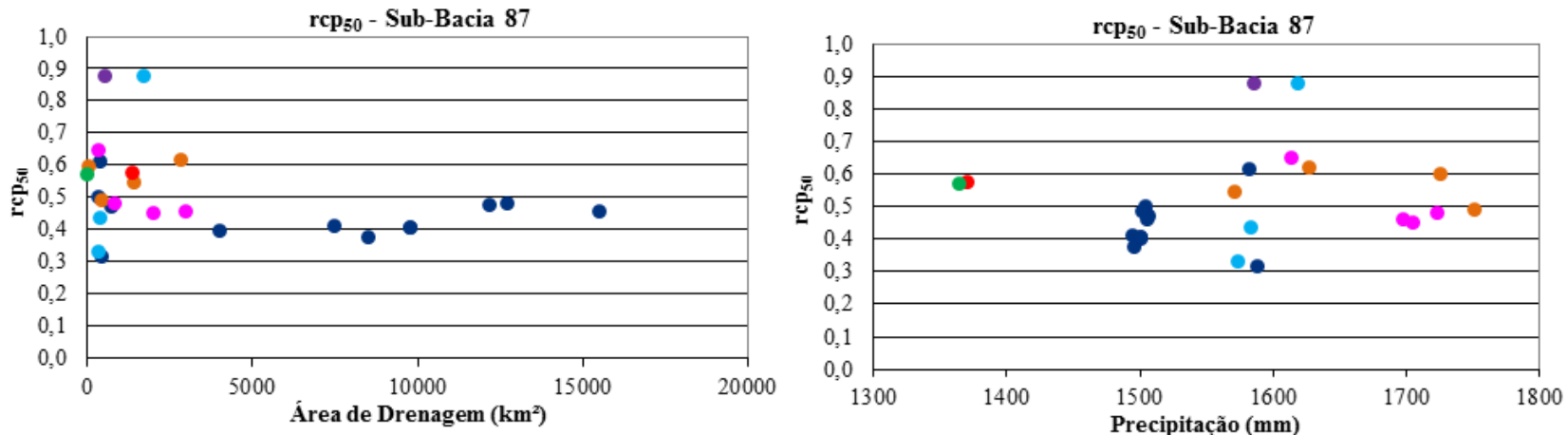

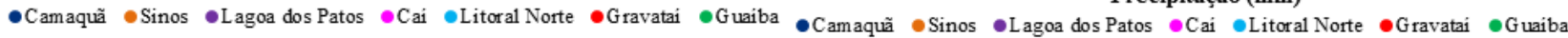
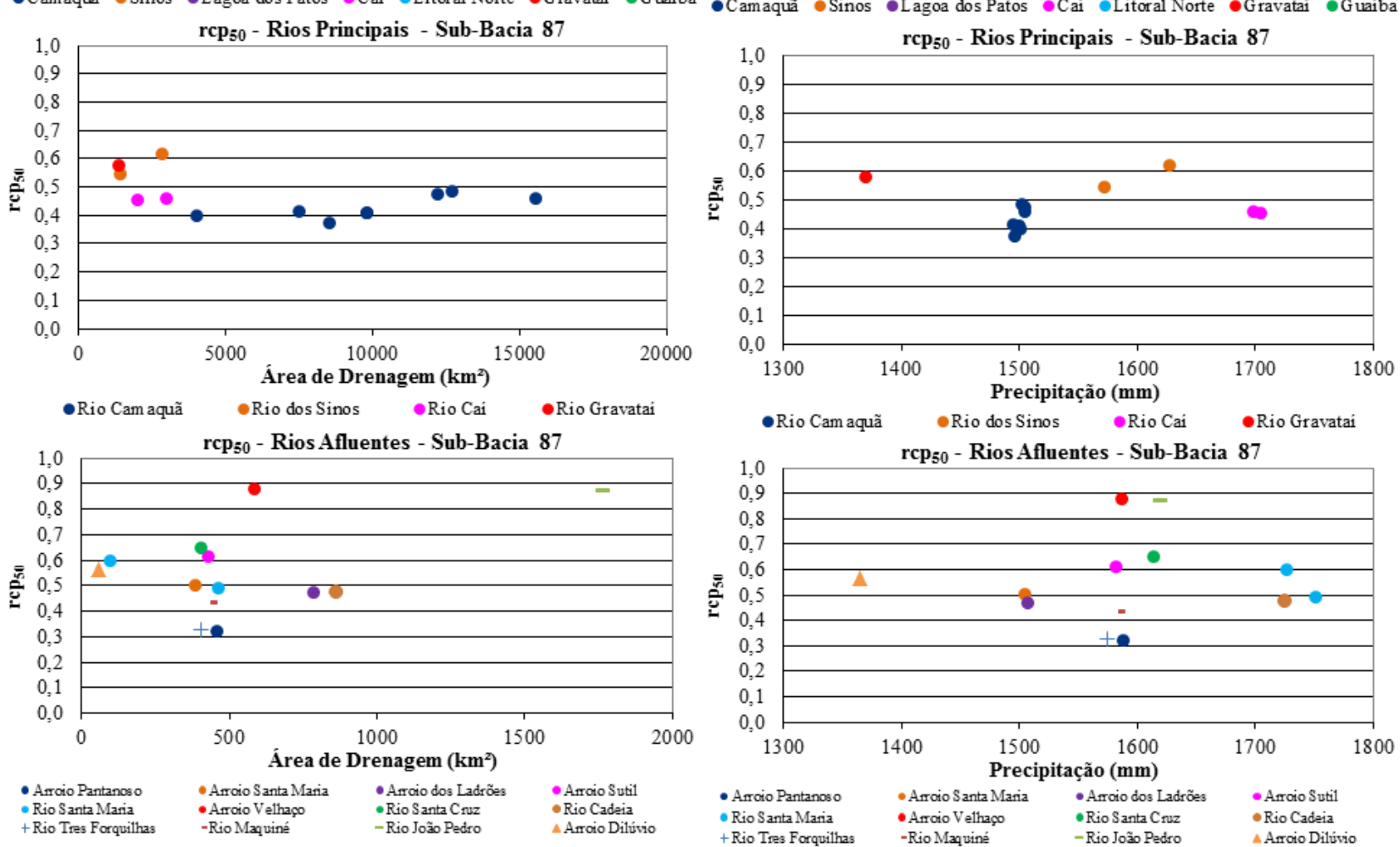

+Rio Tres Forquilhas $\quad$-Rio Mąuinás $\quad$-Rio João Pedro $\quad \Delta$ Arroio Dilúvio

Figura 4 - Dispersão do indicador da variabilidade regional $\mathrm{rcp}_{50}$, das estações fluviométricas utilizadas neste estudo, segundo a sua respectiva área de drenagem e a precipitação média anual.

Averígua-se também na Figura 5 que a rcp95, considerando a precipitação pluviométrica média a montante da estação, apresenta-se distribuída em valores aproximadamente homogêneos de precipitação em cada sub-bacia. Isto pode ser visualizado principalmente na sub-bacia do rio Camaquã, que apresenta precipitação em torno de $1500 \mathrm{~mm}$ para todas as estações localizadas ao longo do rio. No rio Caí as estações Nova Palmira (código 87160000) e Barca do Caí (código 87170000) apresentam precipitação próxima a 1700mm, e rcp95 próximo a 0,10. Para os rios afluentes, visualiza-se valores da rcp95 próximos (cerca de 0,15 ), com precipitação em torno de 1500mm, para as estações Passo dos Ladrões (código 87850000) em Arroio dos Ladrões e Passo 
Maria Santa (código 87810000) em Arroio Santa Maria, ambas localizadas em afluentes que desaguam na margem esquerda do rio Camaquã. Observam-se também valores de 0,20 para as estações Dom Feliciano (código 87865000, sub-bacia do rio Camaquã) em Arroio Sutil e Camaquã I (código 87530000, sub-bacia da Lagoa dos Patos) em Arroio Velhaço, estações próximas, embora localizadas em sub-bacias distintas. Por último, também observa-se valores em torno de 0,065 para as estações Passo do Louro (código 87366000, sub-bacia do rio dos Sinos) e Costa do Rio Cadeia (código 87250000, sub-bacia do rio Caí).
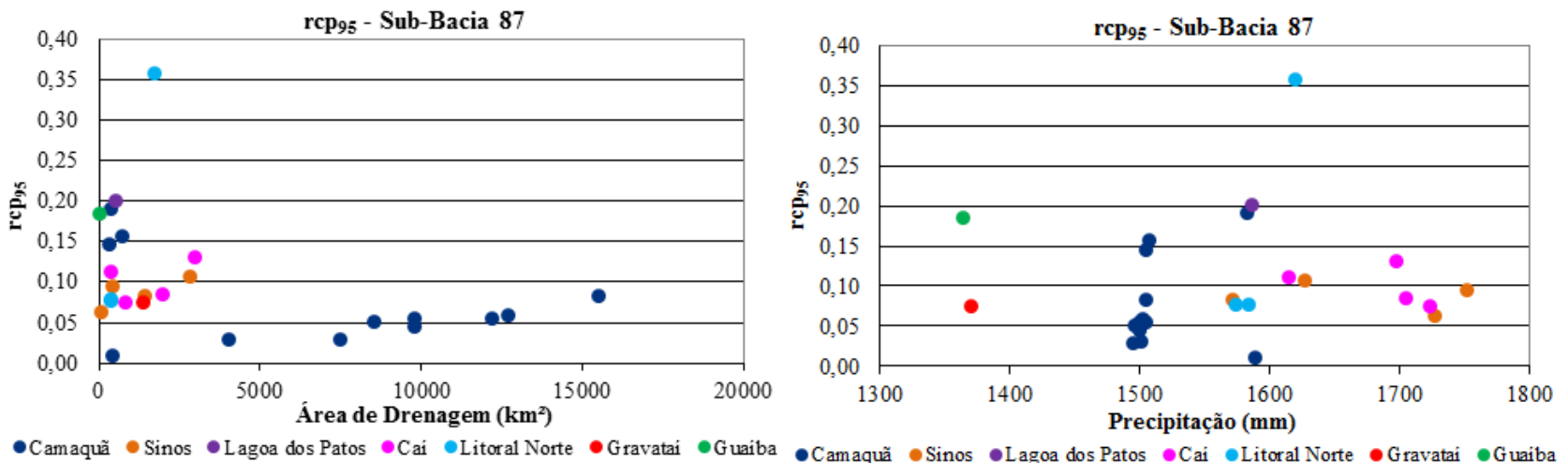

$\bullet$ Camaquã • Sinos $\bullet$ Lagoa dos Patos $\bullet$ Cai $\bullet$ Litoral Norte $\bullet$ Gravatai $\bullet$ Guaiba $\bullet$ Camaquã $\bullet$ Sinos $\bullet$ Lagoa dos Patos $\bullet$ Cai $\bullet$ Litoral Norte $\bullet$ Gravatai $\bullet$ Guaiba
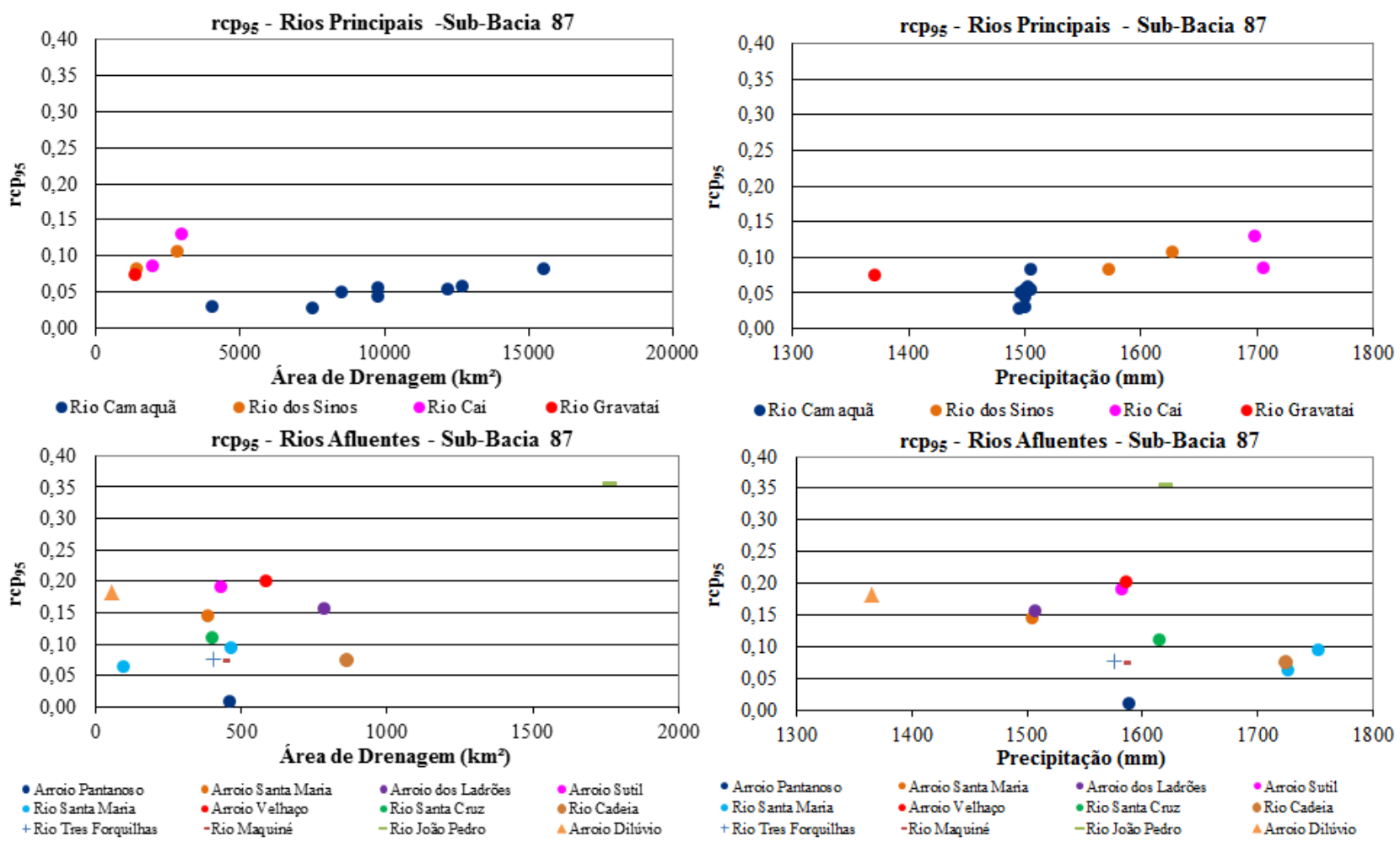

Figura 5 - Dispersão do indicador da variabilidade regional $\mathrm{rcp}_{95}$, das estações fluviométricas utilizadas neste estudo, segundo a sua respectiva área de drenagem e precipitação média anual.

Observa-se na Figura 6 que o Coeficiente de Escoamento Superficial, considerando a área de drenagem, apresenta valores entre 0,10 e 0,70 tanto para os rios principais quanto para os rios afluentes. Os valores mais baixos em estações fluviométricas nos rios principais, que variam em 
torno de 0,20, ocorrem para as estações Passo do Marinheiro (código 87730001, área de drenagem $9821 \mathrm{~km}^{2}$ ), Passo da Guarda (código 87820000, área de drenagem 12233km²) e Passo São José (código 87840000, área de drenagem $12732 \mathrm{~km}^{2}$ ), localizadas ao longo do rio Camaquã. Nos rios afluentes os valores mais baixos, que variam em torno de 0,19 , também ocorrem na sub-bacia do rio Camaquã, para as estações Passo Pantanoso (código 87780000, área de drenagem 464km²) em Arroio Pantanoso, Passo Maria Santa (código 87810000, área de drenagem $391 \mathrm{~km}^{2}$ ) em Arroio Maria Santa e Passo dos Ladrões (código 87850000, área de drenagem 788km²) em Arroio dos Ladrões. Os valores mais elevados em estações fluviométricas nos rios principais e nos afluentes, com valor médio de 0,56, ocorrem nas estações Passo das Carretas (código 86700000, área de drenagem $7541 \mathrm{~km}^{2}$ ) no rio Camaquã, Dom Feliciano (código 87865000 , área de drenagem $435 \mathrm{~km}^{2}$ ) no Arroio Sutil, Ipiranga (código 87450100, área de drenagem $57 \mathrm{~km}^{2}$ ) no Arroio Dilúvio e as estações Itati (código 87310000, área de drenagem 403km²), Maquiné (código 87317030, área de drenagem 440 $\mathrm{km}^{2}$ ) e Barra do João Pedro Montante (código 87317060, área de drenagem $1765 \mathrm{~km}^{2}$ ), todas na sub-bacia do Litoral Norte. Valores mais baixos de $\mathrm{C}_{\text {escoamento }}$ indicam baixo escoamento, enquanto que valores elevados indicam que uma boa parte da água precipitada está escoando, ou seja, ocorre menor infiltração, evaporação e evapotranspiração.

Verifica-se na Figura 6 que o Coeficiente de Escoamento Superficial, considerando a precipitação pluviométrica média a montante da estação, apresenta-se distribuído em valores aproximadamente homogêneos de precipitação em cada sub-bacia. Isto pode ser visualizado principalmente na sub-bacia do rio Camaquã, que apresenta precipitação em torno de $1500 \mathrm{~mm}$ para todas as estações localizadas ao longo do rio. Na sub-bacia do rio Caí, as estações Nova Palmira (código 87160000) e Barca do Caí (código 87170000) possuem precipitação próxima a 1700mm, para um valor de $\mathrm{C}_{\text {escoamento }}$ em torno de 0,38 .

Observa-se na Figura 7 que a Vazão Específica da $Q_{\text {mlt }}$, considerando a área de drenagem, apresenta valores entre $91 . \mathrm{s}^{-1} \cdot\left(\mathrm{km}^{2}\right)^{-1}$ e $1 . \mathrm{s}^{-1} \cdot\left(\mathrm{km}^{2}\right)^{-1}$ para os rios principais e entre $61 . \mathrm{s}^{-1} \cdot\left(\mathrm{km}^{2}\right)^{-1}$ e 31 $1 . \mathrm{s}^{-1} .\left(\mathrm{km}^{2}\right)^{-1}$ para os rios afluentes. Os valores mais baixos em estações fluviométricas nos rios principais ocorrem para três estações localizadas no rio Camaquã, que são Passo do Marinheiro (código 87730001, área de drenagem 9821km²), Passo da Guarda (código 87820000, área de drenagem $12233 \mathrm{~km}^{2}$ ) e Passo São José (código 87840000, área de drenagem $12732 \mathrm{~km}^{2}$ ), com valor médio de $Q_{\text {mlt esp }}$ de $9,51 . \mathrm{s}^{-1} .\left(\mathrm{km}^{2}\right)^{-1}$. Visualiza-se no gráfico dos rios afluentes, que os menores valores encontrados para este indicador foram para as estações Passo Pantanoso (código 87780000 , área de drenagem $\left.464 \mathrm{~km}^{2}\right)$ em Arroio Pantanoso, com 6,66 $1 . \mathrm{s}^{-1} .\left(\mathrm{km}^{2}\right)^{-1}$, Passo Maria Santa em Arroio Santa Maria (código 87810000, área de drenagem $\left.391 \mathrm{~km}^{2}\right)$, com 8,90 $1 . \mathrm{s}^{-1} .\left(\mathrm{km}^{2}\right)^{-1}$ e Passo dos Ladrões (código 87850000, área de drenagem $788 \mathrm{~km}^{2}$ ) em Arroio dos Ladrões, com 12,17 1.s ${ }^{1} .\left(\mathrm{km}^{2}\right)^{-1}$, todas localizadas em afluentes da sub-bacia do rio Camaquã. Já os valores mais elevados 
de $\mathrm{Q}_{\text {mlt esp }}$ ocorrem em várias estações nos rios principais e afluentes, com valores entre 22,43 1.s ${ }^{1} .\left(\mathrm{km}^{2}\right)^{-1}$ e $30,811 . \mathrm{s}^{-1} .\left(\mathrm{km}^{2}\right)^{-1}$, localizadas nas sub-bacias do rio Camaquã, rio dos Sinos, rio Caí, Guaíba e Litoral Norte. As três estações da sub-bacia do Litoral Norte apresentam valores elevados, e são Itati em rio Três Forquilhas (código 87310000, área de drenagem 403km²), com 24,8 1.s ${ }^{1} .\left(\mathrm{km}^{2}\right)^{-1}$, Maquiné em rio Maquiné (código 87317030, área de drenagem 440km²), com 30,8 1.s ${ }^{1} .\left(\mathrm{km}^{2}\right)^{-1}$, e Barra do João Pedro Montante em rio João Pedro (código 87317060, área de drenagem $\left.1765 \mathrm{~km}^{2}\right)$, com $27,71 . \mathrm{s}^{-1} .\left(\mathrm{km}^{2}\right)^{-1}$. Valores mais elevados de $\mathrm{Q}_{\mathrm{mlt}}$ esp indicam que um maior volume de água está sendo produzido, por um determinado tempo, para a área de drenagem da estação.
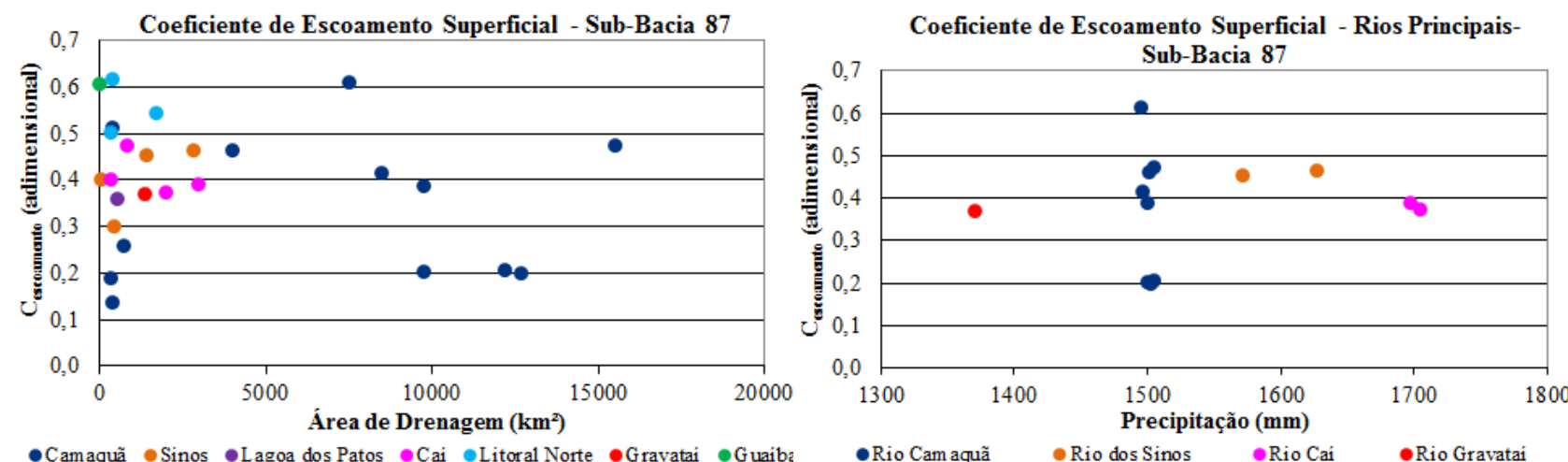

-Camaquã - Sinos $\bullet$ Lagoa dos Patos $\bullet$ Cai $\bullet$ Litoral Norte $\bullet$ Gravatai $\bullet$ Guaib Coeficiente de Escoamento Superficial - Rios Principais-
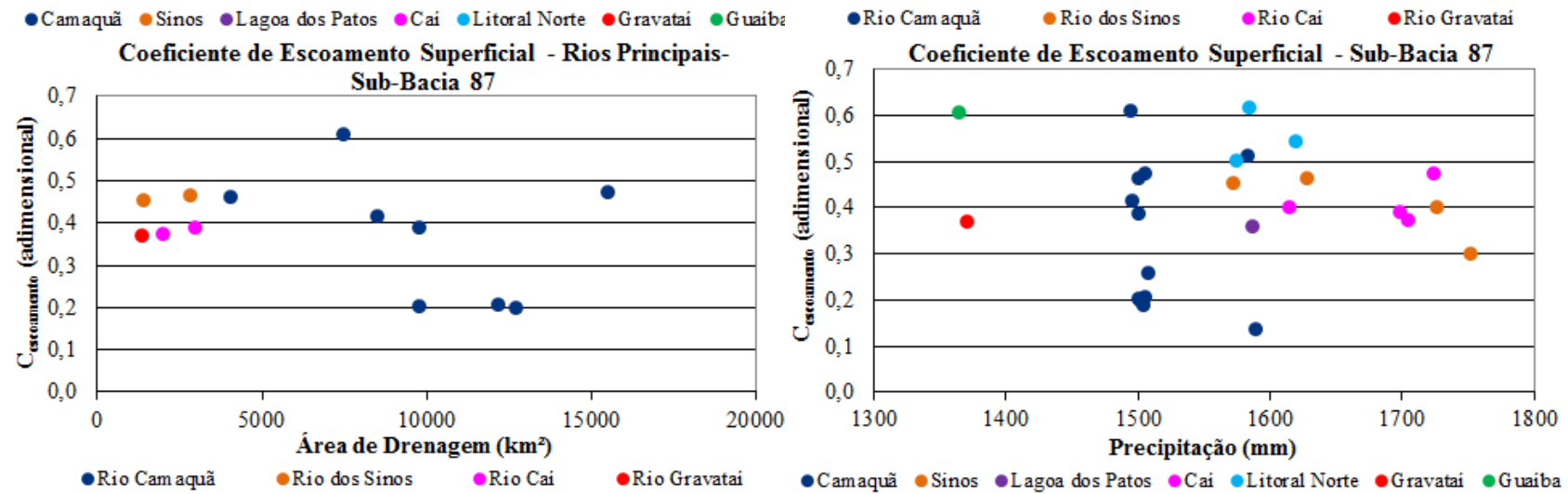

Coeficiente de Escoamento Superficial - Rios Afluentes -

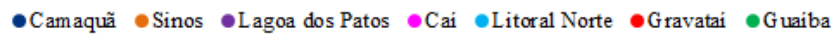
Coeficiente de Escoamento Superficial - Rios Afluentes -
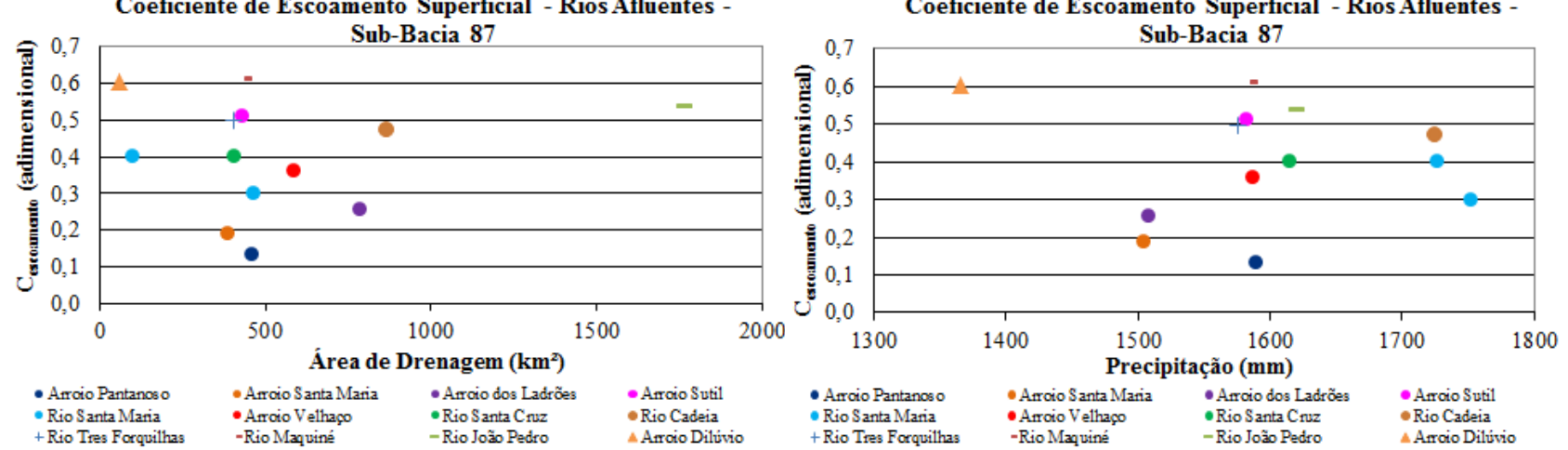

Figura 6 - Dispersão do indicador da variabilidade regional coeficiente de escoamento superficial, das estações fluviométricas utilizadas neste estudo, segundo a sua respectiva área de drenagem e precipitação média anual, plotadas por sub-bacia, rios principais e rios afluentes.

Verifica-se na Figura 8 que a Vazão Específica da $\mathrm{Q}_{\mathrm{mlt}}$, considerando a precipitação pluviométrica média a montante da estação, apresenta-se distribuído em valores aproximadamente 
homogêneos de precipitação em cada sub-bacia. Isto pode ser visualizado principalmente na subbacia do rio Camaquã, que apresenta precipitação em torno de $1500 \mathrm{~mm}$ para todas as estações localizadas ao longo do rio. Como pode ser visualizado no gráfico dos rios principais, no rio Caí as estações Nova Palmira (código 87160000) e Barca do Caí (código 87170000) apresentam precipitação próxima a $1700 \mathrm{~mm}$, e $\mathrm{Q}_{\mathrm{mlt}}$ esp próxima a $20,451 . \mathrm{s}^{-1} \cdot\left(\mathrm{km}^{2}\right)^{-1}$. Para os rios afluentes, visualiza-se valores deste indicador próximos (aproximadamente $251 . \mathrm{s}^{-1} .\left(\mathrm{km}^{2}\right)^{-1}$ ), com precipitação em torno de $1575 \mathrm{~mm}$, para as estações Itati (código 87310000) em rio Três Forquilhas e Dom Feliciano (código 87865000) em Arroio Sutil.

Observa-se na Figura 9 que a Vazão Específica da Q $_{95}$, considerando a área de drenagem, apresenta valores entre $11 . \mathrm{s}^{-1} .\left(\mathrm{km}^{2}\right)^{-1}$ e $201 . \mathrm{s}^{-1} .\left(\mathrm{km}^{2}\right)^{-1}$ para os rios principais e entre $0,011 . \mathrm{s}^{-1} .\left(\mathrm{km}^{2}\right)^{-}$ 1 e $121 . \mathrm{s}^{-1} .\left(\mathrm{km}^{2}\right)^{-1}$ para os rios afluentes. Os valores mais baixos em estações fluviométricas nos rios principais ocorrem para várias estações, sendo aquelas com valores mais baixos Passo das Canoas Auxiliar (código 87399000, área de drenagem $1416 \mathrm{~km}^{2}$ ), com $1,201 . \mathrm{s}^{-1} .\left(\mathrm{km}^{2}\right)^{-1}$ no rio Gravataí, Taquara-Montante (código 87374000, área de drenagem $\left.1466 \mathrm{~km}^{2}\right)$, com 1,69 $1 . \mathrm{s}^{-1} .\left(\mathrm{km}^{2}\right)^{-1}$ no rio dos Sinos e Passo do Cação (código 87590000, área de drenagem 4073km²), com 1,66 1.s ${ }^{1} .\left(\mathrm{km}^{2}\right)^{-1}$ no rio Camaquã. Visualiza-se no gráfico dos rios afluentes, que os menores valores encontrados para este indicador também são de várias estações, sendo os menores para estações com $Q_{95}$ esp menores que 0,20, entre elas Passo Pantanoso (código 87780000, área de drenagem $\left.464 \mathrm{~km}^{2}\right)$ em Arroio Pantanoso, com 0,016 1. $\mathrm{s}^{-1} .\left(\mathrm{km}^{2}\right)^{-1}$, Passo Maria Santa em Arroio Santa Maria (código 87810000, área de drenagem $101 \mathrm{~km}^{2}$ ), com 0,078 1.s $\mathrm{s}^{-1} .\left(\mathrm{km}^{2}\right)^{-1}$ e Ipiranga (código 87450100 , área de drenagem $\left.57 \mathrm{~km}^{2}\right)$ em Arroio Dilúvio, com $0,1991 . \mathrm{s}^{-1} .\left(\mathrm{km}^{2}\right)^{-1}$. Já os maiores valores ocorrem para a estação Passo do Mendonça com 18,72 $1 . \mathrm{s}^{-1} .\left(\mathrm{km}^{2}\right)^{-1}$ (código 87905000, área de drenagem $15557 \mathrm{~km}^{2}$, localizada a jusante no rio Camaquã e para a estação Barra do João Pedro - Montante, com $10,741 . \mathrm{s}^{-1} .\left(\mathrm{km}^{2}\right)^{-1}$ (código 87317060 , área de drenagem $1765 \mathrm{~km}^{2}$ ), localizada na sub-bacia do Litoral Norte. Valores mais elevados de $\mathrm{Q}_{95}$ esp indicam que um maior volume de água está sendo produzido no período de estiagem, em um determinado tempo, para a área de drenagem da estação.

Verifica-se na Figura 10 que a Vazão Específica da $\mathrm{Q}_{\mathrm{mlt}}$, considerando a precipitação pluviométrica média a montante da estação, apresenta-se distribuído em valores aproximadamente homogêneos de precipitação em cada sub-bacia. Isto pode ser visualizado principalmente na subbacia do rio Camaquã, que apresenta precipitação em torno de $1500 \mathrm{~mm}$ para todas as estações localizadas ao longo do rio. Como pode ser visualizado no gráfico dos rios principais, não há estações com valores próximos de $\mathrm{Q}_{95}$ esp. Para os rios afluentes, visualiza-se valores deste indicador idênticos $\left(1,331 . \mathrm{s}^{-1} \cdot\left(\mathrm{km}^{2}\right)^{-1}\right)$, com precipitação em torno de $1586 \mathrm{~mm}$, para as estações Camaquã I (código 87530000) em Arroio Velhaço e Dom Feliciano (código 87865000) em Arroio Sutil. Um maior detalhamento destes resultados podem ser verificados em Marcuzzo e Pickbrenner (2016) 


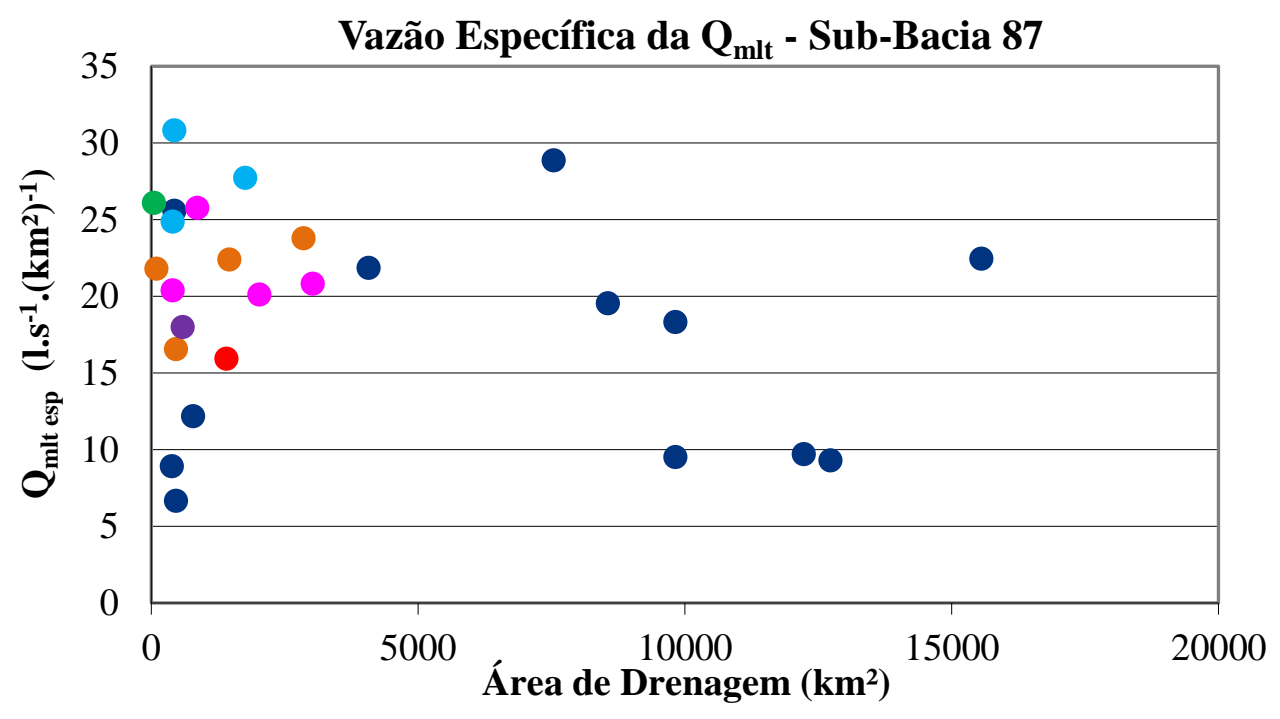

- Camaquã • Sinos • Lagoa dos Patos • Caí • Litoral Norte • Gravataí • Guaíba

Vazão Específica da $Q_{\mathrm{mlt}}$ - Rios Principais -
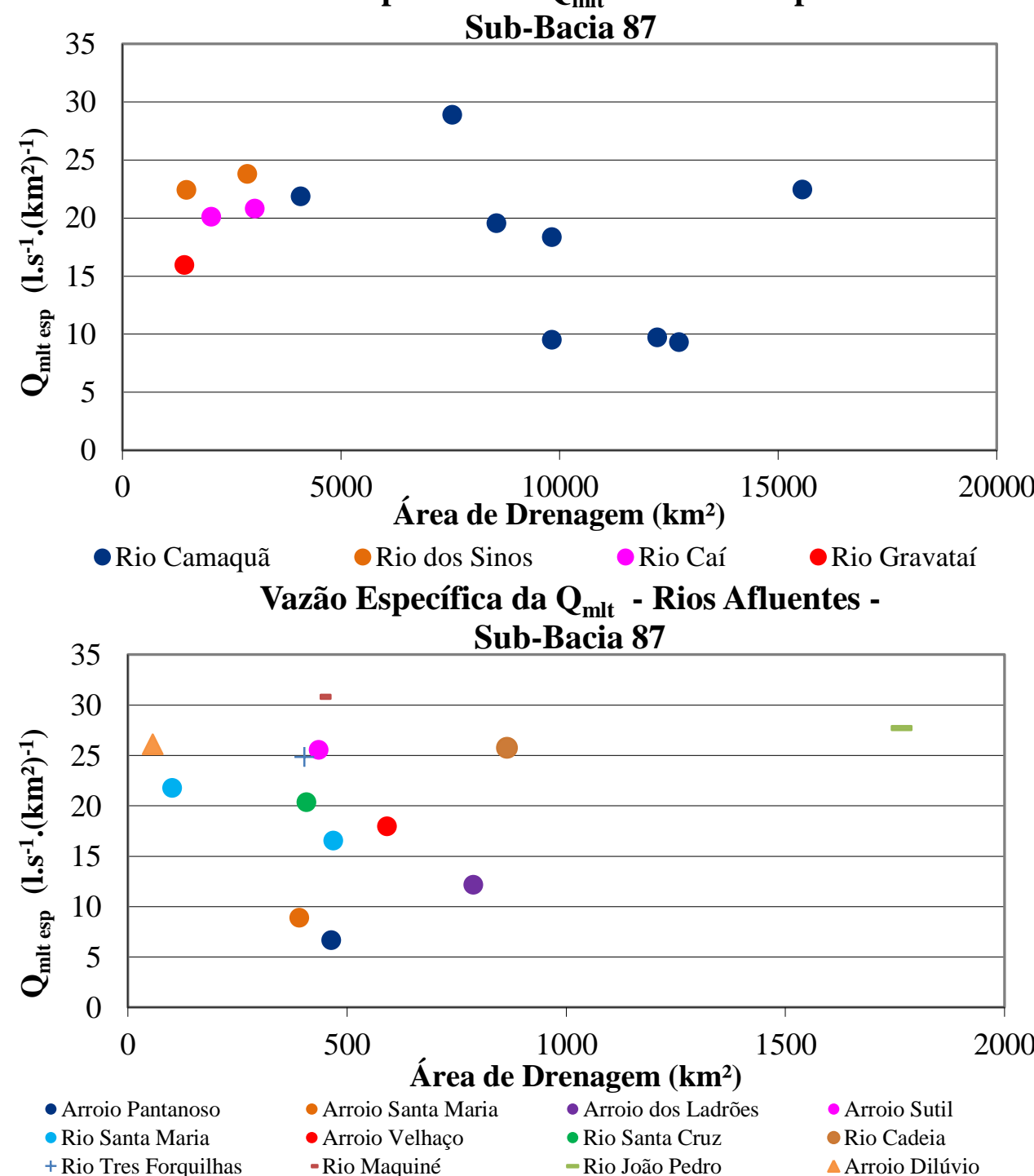

Figura 7 - Dispersão do indicador da variabilidade regional das vazões médias específicas de longo período, das estações fluviométricas utilizadas neste estudo, segundo a sua respectiva área de drenagem, plotadas por sub-bacia, rios principais e rios afluentes. 


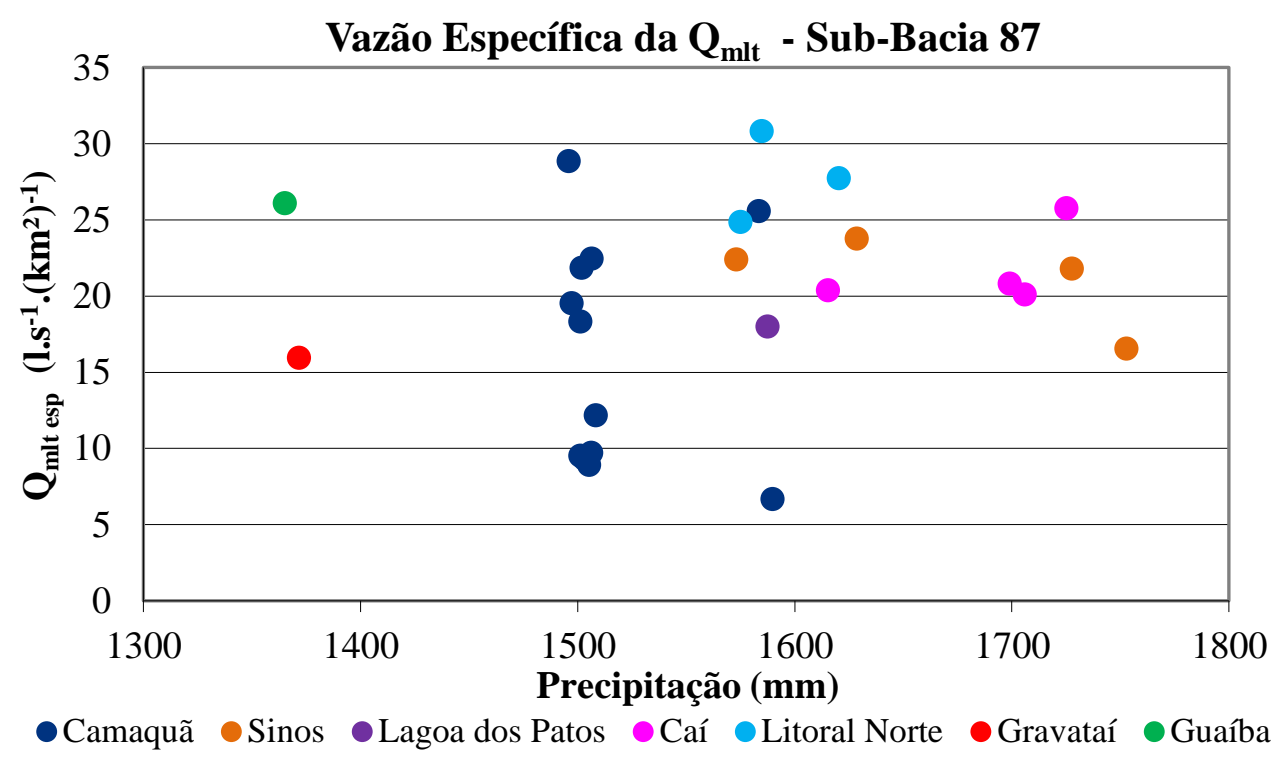

Vazão Específica da $\mathbf{Q}_{\mathrm{mlt}}$ - Rios Principais -

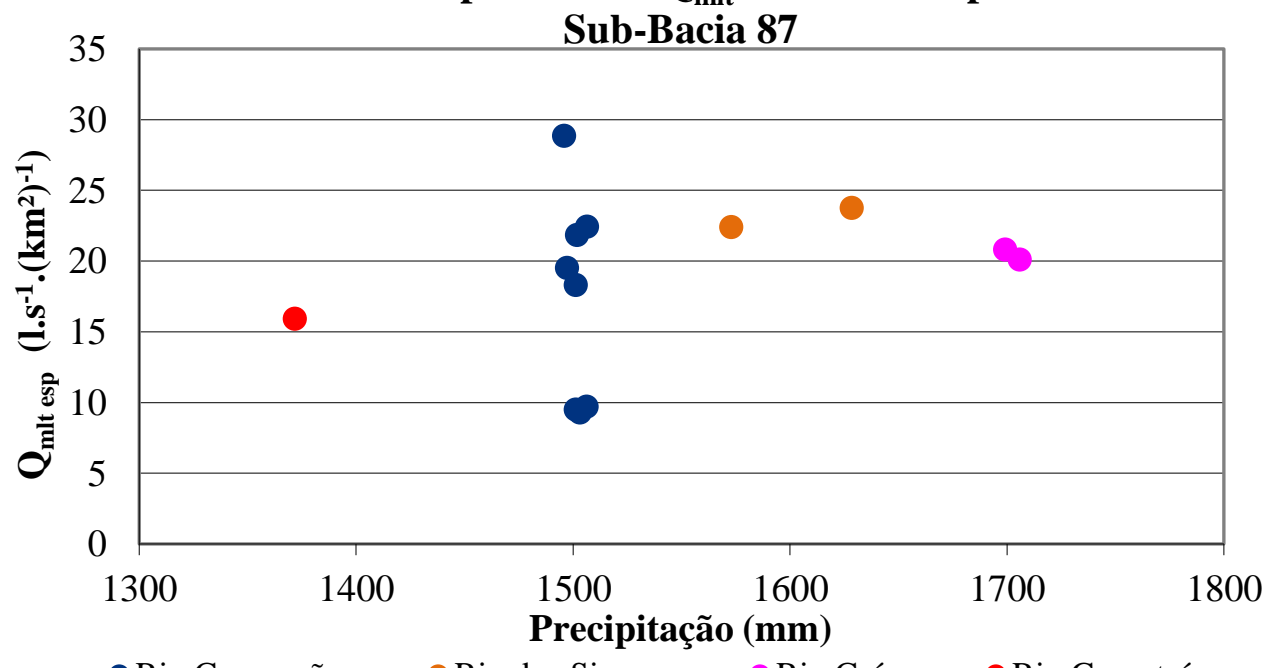

- Rio Camaquã O Rio dos Sinos C Rio Caí ORio Gravataí

Vazão Específica da $\mathbf{Q}_{\mathrm{mlt}}$ - Rios Afluentes -

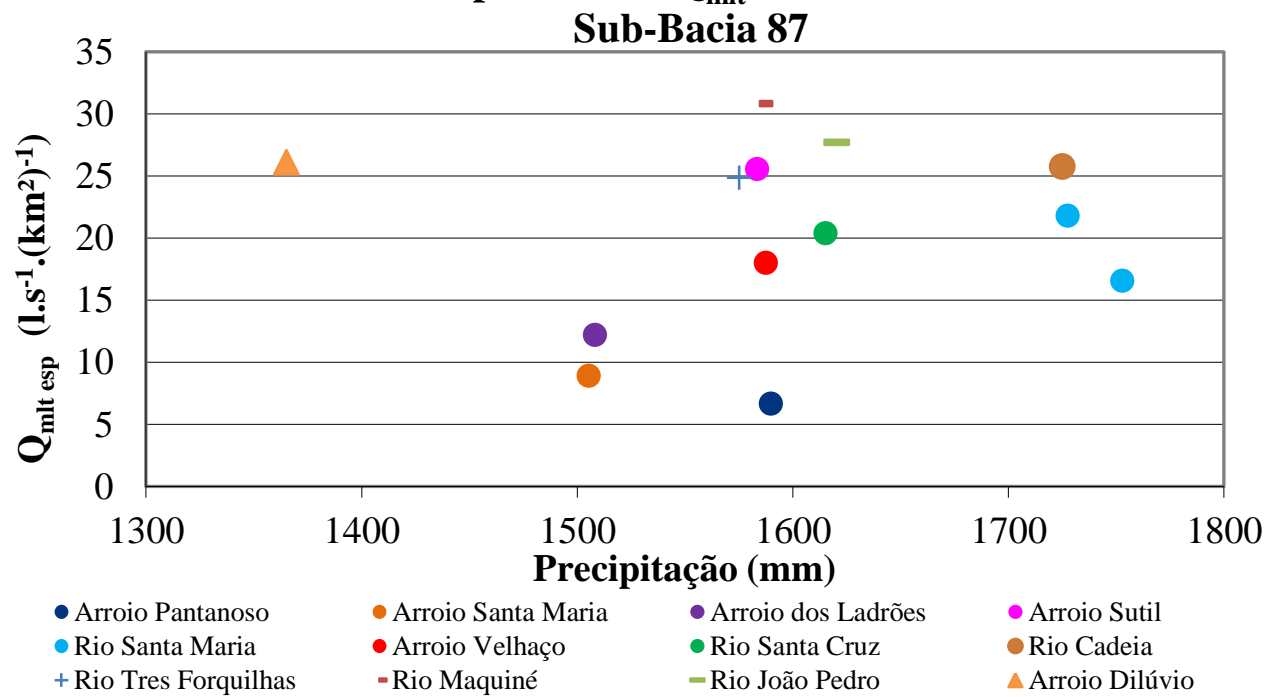

Figura 8 - Dispersão do indicador da variabilidade regional das vazões médias específicas de longo período, das estações fluviométricas utilizadas neste estudo, segundo a sua respectiva precipitação média anual, plotadas por sub-bacia, rios principais e rios afluentes. 


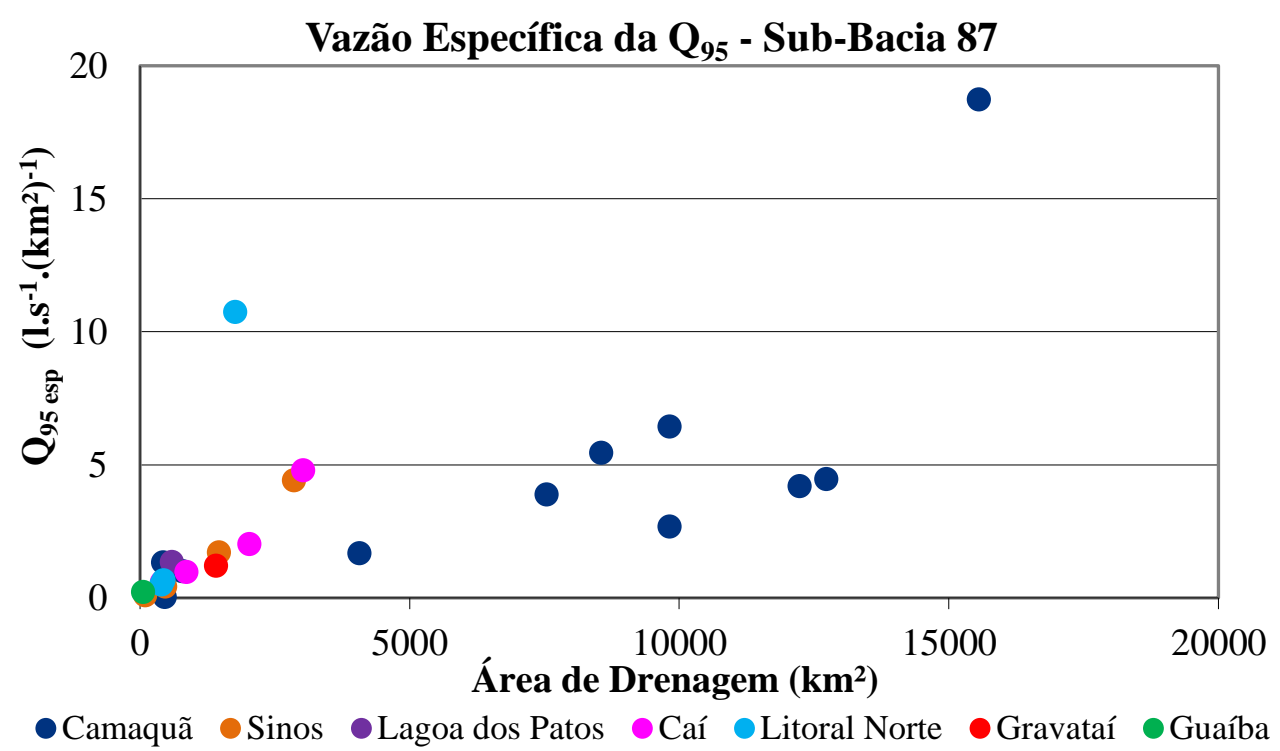

Vazão Específica da $\mathbf{Q}_{95}$ - Rios Principais -

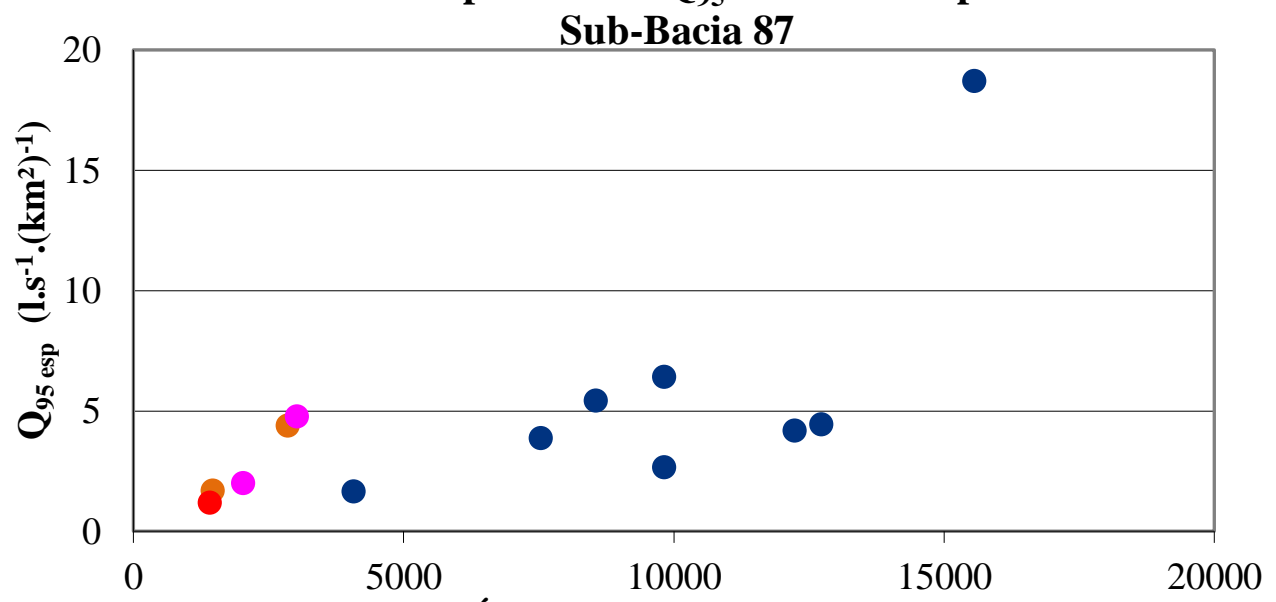

Área de Drenagem $\left(\mathrm{km}^{2}\right)$

- Rio Camaquã O Rio dos Sinos @ Rio Caí Rio Gravataí

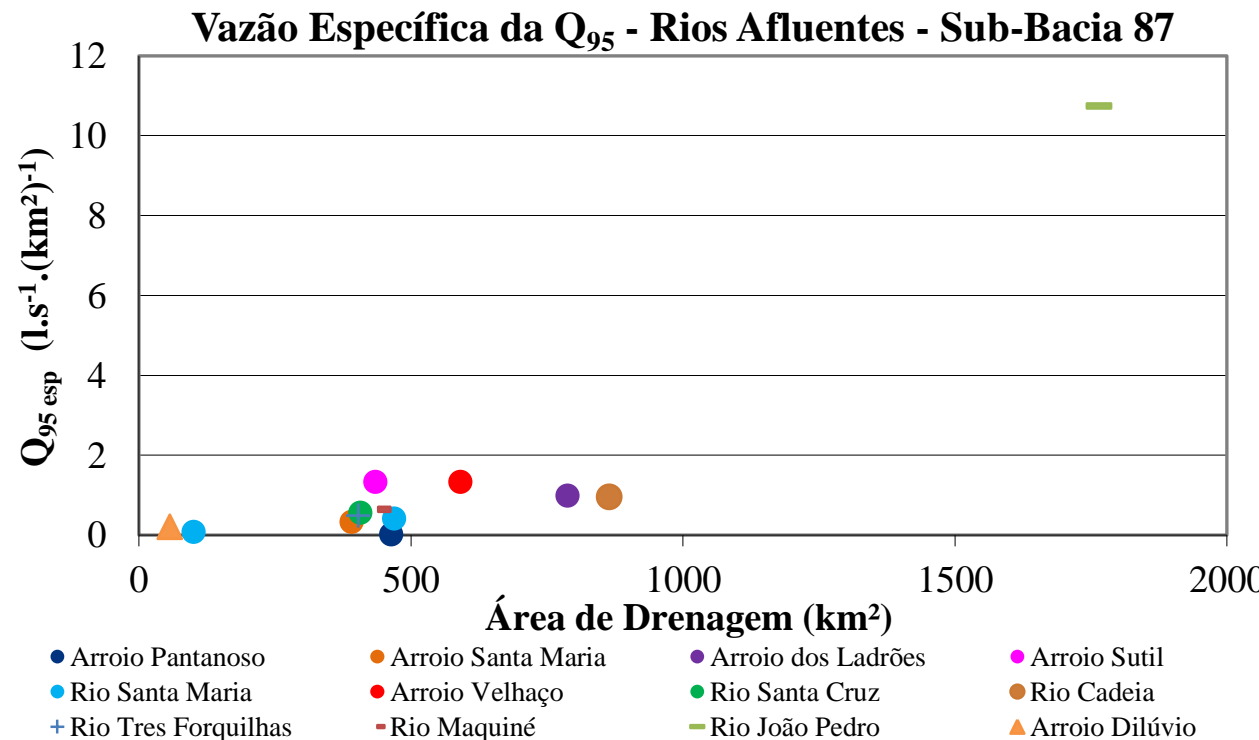

Figura 9 - Dispersão do indicador da variabilidade regional das vazões específicas de $95 \%$ de permanência, das estações fluviométricas utilizadas neste estudo, segundo a sua respectiva área de drenagem, plotadas por sub-bacia, rios principais e rios afluentes. 


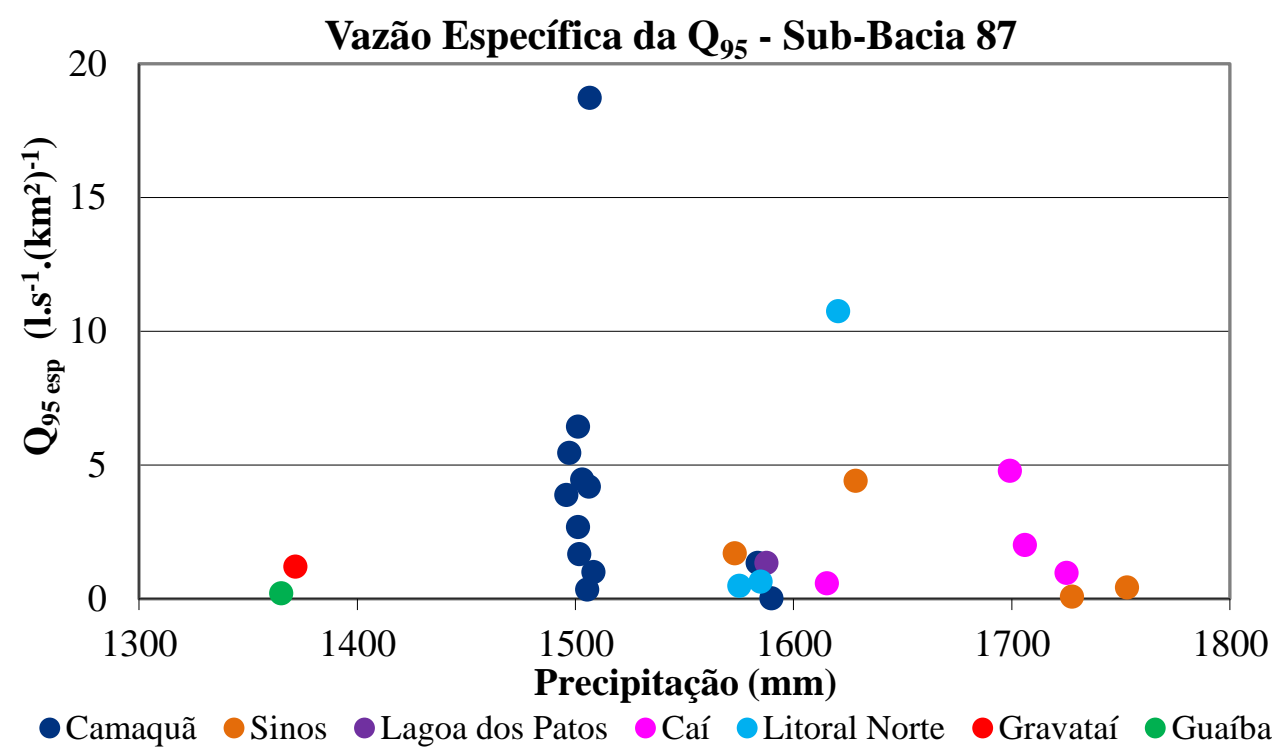

Vazão Específica da $\mathbf{Q}_{95}$ - Rios Principais -
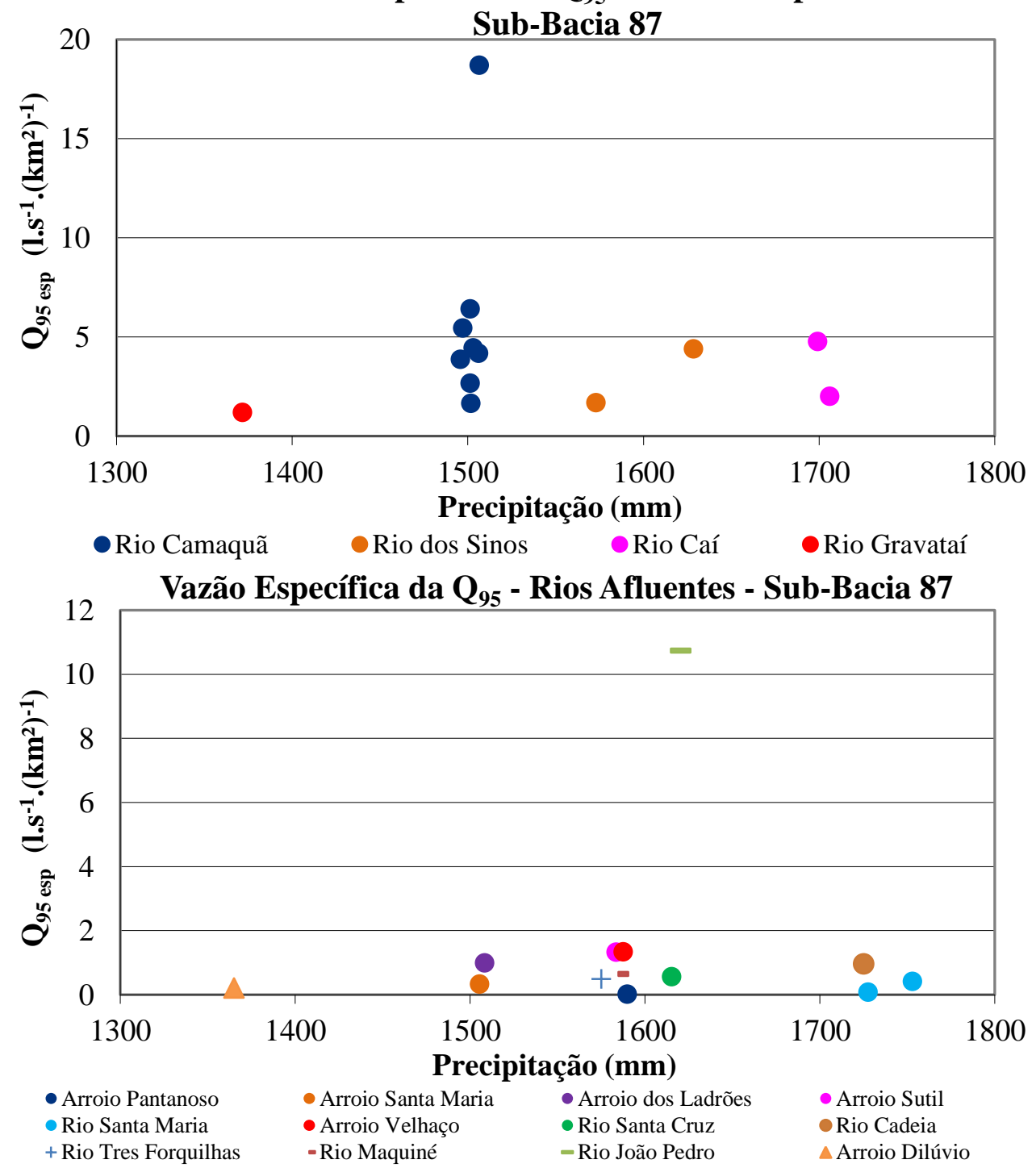

Figura 10 - Dispersão do indicador da variabilidade regional das vazões específicas de $95 \%$ de permanência, das estações fluviométricas utilizadas neste estudo, segundo a sua respectiva precipitação média anual, plotadas por sub-bacia, rios principais e rios afluentes. 


\section{CONCLUSÃO}

Com os indicadores CVQmlt e CVQ95 percebeu-se que seus valores mais baixos ocorrem no trecho médio do rio Camaquã, assim como em várias outras sub-bacias. Quanto aos valores mais elevados, eles ocorrem para ambos os indicadores na cabeceira do rio Camaquã, além de outras estações na sub-bacia.

Já com os indicadores rcp50 e rcp95percebeu-se que seus valores mais baixos ocorrem para várias estações localizadas ao longo do rio Camaquã. Quanto aos valores mais elevados, para a rcp50, estes ocorrem em estações nas sub-bacias da Lagoa dos Patos e do Litoral Norte. Para a rcp95, os maiores valores estão em estações localizadas em quatro sub-bacias distintas.

Já para o indicador Coeficiente de Escoamento, observa-se que os menores valores ocorrem em estações ao longo do rio Camaquã, enquanto que os maiores valores ocorrem para todas as estações da sub-bacia do Litoral Norte.

E, por fim, com os indicadores Qmltesp e Q95esp, nota-se que os valores menores de Qmltesp ocorrem para várias estações na sub-bacia do rio Camaquã, enquanto que para a Q95esp também há estações em várias outras sub-bacias. Para os maiores valores destes indicadores, para a Qmltesp estes ocorrem em várias estações, enquanto que para a Q95esp o maior valor ocorre para a estação mais a jusante do rio Camaquã.

\section{AGRADECIMENTO}

O autor agradece a CPRM/SGB (Companhia de Pesquisa Recursos Minerais / Serviço Geológico do Brasil - Empresa Pública do Ministério de Minas e Energia) pelo fomento.

\section{REFERÊNCIAS BIBLIOGRÁFICAS}

BRASIL. Agência Nacional de Águas. Hidroweb: Sistema de informações hidrológicas. Disponível em: <http://www.hidroweb.ana.gov.br>. Acesso em: 29 mai. 2013.

KICH, E. de M.; MELATI, M. D.; MARCUZZO, F. F. N. Estudo do regime hídrico pluvial e fluvial na sub-bacia 86 visando a determinação do seu ano hidrológico. In: Simpósio Brasileiro de Recursos Hídricos, 21, 2015, Brasília. Anais... Porto Alegre: ABRH, 2015. p. 1-8. Disponível em: <https://drive.google.com/open?id=0B6T7sNg_aVgOZFloU1NUYjFHQWs >. Acesso em: 30 dez. 2015.

MACHADO, J. L. F.; MARCUZZO, F. F. N. Estudo do regime hídrico pluvial e fluvial na subbacia 86 visando a determinação do seu ano hidrológico. In: Simpósio Brasileiro de Recursos Hídricos, 21, 2015, Brasília. Anais... Porto Alegre: ABRH, 2015. p. 1-8. Disponível em: 
<https://drive.google.com/open?id=0B6T7sNg_aVgOWEtLbVJxN0tHQ0U〉. Acesso em: $30 \mathrm{dez}$. 2015.

MANZIONE, R. L.; MARCUZZO, F. F. N.; WENDLAND, E. C. Funções de impulso e resposta aplicadas à modelagem de níveis freáticos em área de recarga do Sistema Aquífero Guarani. In: Simpósio Brasileiro de Recursos Hídricos, 18. 2009, Campo Grande. Anais... Campo Grande: ABRH, $2009 . \quad$ v. $1 . \quad$ p. 1-12. Disponível em: <http://www.abrh.org.br/sgcv3/UserFiles/Sumarios/7f39299b4fb59bf84b6a99ce21e30e62_c49fc27 02fce7aaeb1d6c4d163e0055a.pdf>

MANZIONE, R. L.; MARCUZZO, F. F. N.; WENDLAND, E. C. Integração de modelos espaciais e temporais para predições de níveis freáticos extremos. Pesquisa Agropecuária Brasileira, Brasília, v. 47, n. 9, p. 1368-1375, set. 2012. Disponível em: <http://www.scielo.br/pdf/pab/v47n9/22.pdf $>$. Acesso em: 31 mar. 2014.

MANZIONE, R. L.; MARCUZZO, F. F. N.; WENDLAND, E. C. Modelagem de níveis freáticos em área de recarga do Sistema Aquífero Guarani sob diferentes usos do solo. In: Congresso Brasileiro de Águas Subterrâneas, 16. 2010, São Luis: Anais... São Paulo: ABRH, 2010. v. 1. p. 114. Disponível em: 〈http://www.cprm.gov.br/publique/media/evento_PAP004214.pdf〉. Acesso em 08 abr. 2014.

MARCUZZO, F. F. N.; MELATI, M. D. A concepção e mapeamento dos diagramas unifilares das estações fluviométricas nas sub-bacias pertencentes à bacia hidrográfica do atlântico - trecho sudeste. In: Congresso Nacional de Saneamento e Meio Ambiente, 26. (AESABESP), 2015, São Paulo, PR. Anais... São Paulo: SABESP, 2015. P 1-20. 1 DVD. Disponível em: <http://www.evolvedoc.com.br/aesabesp/detalhes-676_a-concepcao-e-mapeamento-dos-diagramas$\underline{\text { unifilares-das-estacoes-fluviometricas-nas-sub-bacias-pertencentes-a-bacia-hidrografica-do- }}$ atlantico-trecho-sudeste>. Acesso em: 26 ago. 2015.

MARCUZZO, F. F. N.; PICKBRENNER, K. Regionalização de Vazões nas Bacias Hidrográficas Brasileiras: estudo da vazão de 80, 85, 90 e $95 \%$ de permanência da sub-bacia 87. Porto Alegre: CPRM, 2016. 1 DVD. Projeto Disponibilidade Hídrica do Brasil - Estudos de Regionalização nas Bacias Hidrográficas Brasileiras. Levantamento da Geodiversidade.

MARCUZZO, F. F. N.; SIMON, F. W.; KIRCHHEIM, R. E. Relação da Hidrogeologia e os Indicadores Regionais de Vazão na Sub-Bacia da Lagoa dos Patos. In: XVIII Congresso Brasileiro de Águas Subterrâneas, 2014, Belo Horizonte. Anais... São Paulo: Editora da Sociedade Brasileira de Águas Subterrâneas, 2014. v. $\quad 1 . \quad$ p. 1-20. Disponível em: $<$ https://drive.google.com/open?id=0B6T7sNg aVgOWnpQVngtY0VoMEU>. Acesso em: 17 set. 2015. 
MELATI, M. D. Regionalização das vazões Q95\%, Q50\% e Q7,10 para a sub-bacia do Taquari-Antas. 2015. 129 f. TCC (Graduação) - Curso de Engenharia Ambiental, UFRGS/IPH, Porto Alegre, 2015. Disponível em: <https://drive.google.com/file/d/0B_S3etRxlvYzVjBTSjlaek9N

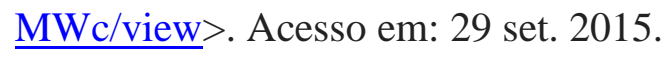

NAGHETTINI, M.; PINTO, É. J. de A. Hidrologia estatística. Belo Horizonte: CPRM, 2007. 561 p. Disponível em: 〈http://www.cprm.gov.br/publique/media/livro_hidro_estatistica.zip〉. Acesso em: 15 mai. 2013.

PINTO, E. J. de A.; AZAMBUJA, A. M. S. de; FARIAS, J. A. M.; SAlGUEIRO, J. P. de B.; PICKBRENNER, K. (Coords.). Atlas pluviométrico do Brasil: isoietas mensais, isoietas trimestrais, isoietas anuais, meses mais secos, meses mais chuvosos, trimestres mais secos, trimestres mais chuvosos. Brasília: CPRM, 2011. 1 DVD. Escala 1.5:000.000. Equipe Executora: Da Costa, Margarida Regueira; Dantas, Carlos Eduardo de Oliveira; De Azambuja, Andressa Macêdo Silva; Do Nascimento, Jean Ricardo da Silva; Dos Santos, André Luis M. Real; Farias, José Alexandre Moreira; Machado, Érica Cristina; Marcuzzo, Francisco Fernando Noronha; Medeiros, Vanesca Sartorelli; Melo, Denise Christina de Rezende; Rodrigues, Paulo de Tarso R.; Weschenfelder, Adriana Burin; Sistema de Informação Geográfica-SIG - versão 2.0 - atualizada em novembro/2011; Programa Geologia do Brasil; Levantamento da Geodiversidade. Disponível em: <http://www.cprm.gov.br/publique/cgi/cgilua.exe/sys/start.htm?infoid=1351\&sid=9>. Acesso em: 3 set. 2015.

SIMON, F. W.; PICKBRENNER, K.; MARCUZZO, F. F. N. Estudo do regime pluvial e fluvial em bacia hidrográfica com precipitação homogênea. In: Simpósio de Recursos Hídricos do Nordeste, 20. 2013, Bento Gonçalves. Anais... Porto Alegre: ABRH, 2013. p. 1-8. CD-ROM. Disponível em: <http://www.abrh.org.br/SGCv3/UserFiles/Sumarios/22de4a642c2c18259e4809409096e0ff_6f2356 d4ea7d3fcaba0d55bad04ebea4.pdf>. Acesso em: 16 jun. 2014.

TSCHIEDEL, A. da F.; PICKBRENNER, K.; MARCUZZO, F. F. N. Analise hidromorfológica da sub-bacia 87. In: Simpósio de Recursos Hídricos do Nordeste, 11. 2012, João Pessoa. Anais... Porto Alegre: $2012 . \quad$ p. 1-20. CDRH, <http://www.cprm.gov.br/publique/media/Evento_Analise_Marcuzzo.pdf $>$. Acesso em: 16 jun. 2014.

TUCCI, C. E. M. Regionalização de Vazões. Porto Alegre: UFRGS, 2002. 256 p.

VIRÃES, M. V. Projeto Disponibilidade Hídrica do Brasil - Estudos de Regionalização de Vazões nas Bacias Hidrográficas Brasileiras: regionalização da Q95\% na Sub-bacia 50. Recife: CPRM, 2010. 59p. 1 DVD anexo. Relatório interno. 
VIRÃES, M. V. Regionalização de Vazões nas Bacias Hidrográficas Brasileiras: estudo da vazão de $95 \%$ de permanência da sub-bacia 50 - Bacias dos rios Itapicuru, Vaza Barris, Real, Inhambupe, Pojuca, Sergipe, Japaratuba, Subaúma e Jacuípe. Recife: CPRM, 2014. 1 DVD. Projeto Disponibilidade Hídrica do Brasil - Estudos de Regionalização nas Bacias Hidrográficas Brasileiras. Levantamento da Geodiversidade. Disponível em: <http://www.cprm.gov.br/publique/cgi/cgilua.exe/sys/start.htm?infoid=2998\&sid=36>. Acesso em 2 fev. 2015. 